\title{
Algunas reflexiones en torno al fotoperiodismo y la dictadura en la historiografía argentina reciente
}

\section{Some Reflections on Photojournalism and Dictatorship in Recent Argentinian Historiography}

\author{
Alberto del Castillo Troncoso \\ Instituto de Investigaciones Dr. José María Luis Mora, México | adelcastillo@ \\ institutomora.edu.mx
}

\section{Resumen}

El fotoperiodismo es un espacio fundamental para el estudio de relación entre la imagen y la elaboración de una memoria colectiva en torno a los años de la última dictadura argentina en los espacios públicos. En este artículo se analiza una parte importante de la investigación de Cora Gamarnik, autora de diversos artículos emblemáticos sobre el tema. Se destacan las premisas conceptuales y la crítica de fuentes que subyace en sus aportaciones, y se discuten las bases de la lectura de imagen en torno a uno de los episodios más relevantes de la historia reciente latinoamericana.

Palabras clave: dictadura; fotografía; represión; resistencia; violencia.

\begin{abstract}
Photojournalism is a fundamental space for the study of the relationship between the image and the construction in public spaces of a collective memory in the years of the last Argentinian dictatorship. In this article, a significant portion of the research of Cora Gamarnik, the author of several articles on the issue, is analyzed. This article highlights the conceptual propositions and criticism of the sources underlying her contributions, and discusses the foundations for the interpretation of images concerning one of the most relevant episodes in recent Latin American history.
\end{abstract}

Keywords: Dictatorship; photography; repression; resistance; violence.

Fecha de recepción: 8 de octubre de 2014 Fecha de aceptación: 14 de enero de 2015 


\title{
Algunas reflexiones en torno al fotoperiodismo y la dictadura en la historiografía argentina reciente
}

\author{
Alberto del Castillo Troncoso
}

\section{INTRODUCCIÓN}

T a última dictadura cívico-militar argentina representó la inauguración Lde una etapa de terrorismo de Estado que significó un salto cualitativo respecto a regímenes militares anteriores en el tema de la represión contra la población civil. Dicha represión implicó la planificación y edificación de cientos de lugares de detención, secuestro, tortura y exterminio. ${ }^{1}$ Vezzeti (2001) señala que la enorme importancia que ha adquirido la construcción de una memoria colectiva en torno a los años recientes se desprende directamente de la magnitud de esta represión orquestada desde el propio Estado:

La cuestión de la memoria social en la Argentina ha sido, paradójicamente, una herencia de la última dictadura y se ha implementado como una causa asociada estrechamente a la defensa de los derechos humanos y a la demanda de justicia [...] La vigencia de los temas de la memoria, incluso lo que se puede llamar un deber de memoria, ha dependido de un acontecimiento brutal, una

* Este artículo es uno de los resultados de la estancia sabática que realicé en el Instituto Gino Germani de la Universidad de Buenos Aires a lo largo del año 2014, bajo la coordinación de Ana Longoni y con el apoyo del Instituto Mora y el ConAcyt. Algunos avances de esta investigación fueron presentados en el seminario Arte y Política en América Latina en los Años Ochenta en la UBA y en el de La Mirada Documental del Instituto Mora, coordinado por Rebeca Monroy y un servidor. Agradezco sus orientaciones a Julio Menajovsky, Rubén Chababo, Ludmila da Silva, Marcelo Brodsky, Natalia Fortuny, Claudia Feld, Silvia Hirsch, Lizel Tornay, Eduardo Longoni y, sobre todo, a Cora Gamarnik, con quien sostuve diversas charlas, discusiones y debates a lo largo de muchas horas de aquel fructífero año en la ciudad de Buenos Aires.

${ }^{1}$ El número de personas desaparecidas durante la dictadura oscila entre los 8900 casos documentados por la Comisión Nacional sobre la Desaparición de Personas (CoNADEP) con el presidente Alfonsín y la estimación de 30000 casos por parte de distintos grupos de derechos humanos. 
situación límite para la sociedad y sus instituciones: el terrorismo y la criminalización del Estado ocurridos en una escala nunca vista en el país (p. 46).

Dicha construcción ha pasado en estos 40 años por varias etapas y cambios de perfil, sufriendo y experimentando diversos avances y retrocesos, de acuerdo con las características de cada coyuntura, de la transición democrática post Malvinas a la actualidad. ${ }^{2}$

Esta recuperación no lineal de la memoria, con sus rupturas y continuidades, ha encontrado en la fotografía y sus múltiples usos uno de sus vehículos más importantes de expresión.

En este artículo damos cuenta de algunos de los cambios producidos en la memoria colectiva en Argentina durante las últimas cuatro décadas y enfatizamos el papel que han desempeñado las fotografías en dicho proceso. Para ello comentaremos algunos trabajos de investigación que han reflexionado sobre este tema. Desde distintos lugares y marcos sociales la fotografía ha servido lo mismo para justificar el proyecto militar que para posicionar a importantes grupos disidentes que se convirtieron con los años en iconos y referentes de la lucha ciudadana por la recuperación de un Estado de derecho.

El registro de las imágenes ha servido para documentar la política de represión de la dictadura y también fue utilizado por los militares como instrumento de control y para la fabricación de pruebas documentales que intentaban responsabilizar a otros de sus actos criminales. Las fotografías constituyen un universo privilegiado para explorar los distintos caminos a través de los cuales la memoria construida en torno a la dictadura se ha convertido en un referente importante para este tipo de estudios, no sólo en Argentina sino en otros países de América Latina. ${ }^{3}$

Por ello, en este artículo vamos a realizar una exploración en torno a las maneras como han abordado este problema algunas investigaciones recientes

${ }^{2}$ Con este artículo ya concluido, en vísperas de la calurosa navidad de 2014, Mauricio Macri y Sergio Massa, gobernadores de la ciudad y de la provincia de Buenos Aires, respectivamente, coincidieron en declarar a los medios que Argentina debía cerrar de manera definitiva el capítulo de los derechos humanos. Este posicionamiento político abre nuevas confrontaciones en el tema. Ya no tengo el tiempo ni el espacio para analizar las réplicas y las secuelas de esta definición explícita de una parte del Estado en distintos sectores de la sociedad, pero no quisiera dejar de mencionarla, toda vez que es el indicador más reciente de la vigencia del tema y la necesidad de historizarlo con todas sus tensiones y contradicciones.

${ }^{3}$ Dos libros colectivos que proporcionan elementos de análisis sugerentes y con los que este trabajo dialoga de manera particular son: Blejmar, Fortuny y García (2013) y Feld y Stites (2009).

\section{()(1) $\$$}


en Argentina desde el punto de vista del uso y la circulación de las imágenes fotográficas, en particular las pertenecientes al ámbito del fotoperiodismo. Como podrá verse, la gran mayoría de los trabajos consultados para este análisis han sido publicados en los últimos quince años, por lo que estamos frente a un panorama historiográfico de gran actualidad. Se trata de materiales de reflexión muy recientes, los cuales responden a la discusión y el debate intelectual generados en Argentina y América Latina en los últimos años.

Este análisis se centra en algunos de los usos de las imágenes en el fotoperiodismo, tanto las coberturas pensadas y desplegadas a pie de página desde el poder, como la revisión de la obra de algunos fotógrafos críticos de la dictadura. Todo ello a partir de la reflexión de algunos trabajos de la investigadora Cora Gamarnik (en adelante CG), los cuales representan el ejercicio de síntesis más amplio en torno a esta temática y que habremos de complementar con los trabajos específicos de otros autores. ${ }^{4}$

Considero que este análisis sobre las contribuciones de estos investigadores a este tipo de temas en Argentina nos permitirá también establecer referencias más sólidas que puedan servir como punto de partida para la realización de estudios sobre esta problemática en México y América Latina desde un contexto más amplio. Más allá de las evidentes diferencias entre la dictadura argentina y el Estado autoritario que gobernó en México en los años setenta y ochenta del siglo pasado, nos interesa en esta contribución comenzar a plantear posibles vasos comunicantes en la historia de la fotografía de ambas naciones, que nos permitan pensar en este tipo de problemas desde una perspectiva latinoamericana.

\section{LA HISTORIA OFICIAL}

En toda guerra hay personas que sobreviven, otras que quedan incapacitadas, otras que mueren y otras que desaparecen [...] La desaparición de algunas personas es una consecuencia no deseada de esta guerra. Comprendemos el dolor de aquella madre o esposa que ha perdido a su hijo o marido, del cual no podemos dar noticia, porque se pasó clandestinamente a las filas de la subversión, por

${ }^{4}$ Los artículos más relevantes de la autora sobre estos temas se refieren en la bibliografía de este artículo.

\section{()(1) $(9$}


haber sido presa de la cobardía y no poder mantener su actitud subversiva, porque ha desaparecido al cambiarse el nombre y salir clandestinamente del país o porque en un encuentro bélico su cuerpo al sufrir las explosiones, el fuego o los proyectiles, extremadamente mutilado, no pudo ser reconocido, o por exceso de represión.

General Jorge Rafael Videla, presidente de facto. La Prensa, 15 de septiembre de 1977.

En los años de la dictadura predominó la visión oficial impulsada por el propio gobierno, que ocultó con distintas estrategias las violaciones a los derechos humanos y minimizó sus efectos en amplios sectores de la población, justificando la represión bajo el argumento de la existencia de una guerra necesaria contra una subversión que atentaba contra un ser nacional imaginado por los militares dentro de las coordenadas de la civilización cristiana y occidental. De acuerdo con Lvovich y Bisquert (2008):

La subversión abarcaba toda forma de activación popular, todo comportamiento contestatario en escuelas y fábricas y dentro de la familia, toda expresión no conformista en las artes y la cultura, todo cuestionamiento a la autoridad. Los militares golpistas concibieron a un enemigo inconmensurable, al que, según afirmaban, sólo se podía derrotar a través de la guerra (p. 17).

El fotoperiodismo, un género vinculado con temas tan importantes como el poder, la censura y la opinión pública, representa uno de los espacios privilegiados para analizar la relación entre la imagen y la elaboración de una memoria colectiva en torno a los años de la dictadura. CG ha desarrollado una extensa investigación sobre la historia del fotoperiodismo en Argentina entre la década de los sesenta y los ochenta del siglo pasado. En síntesis, en esta breve incursión crítica a través de la obra de la autora destacaremos algunos de los contenidos temáticos más relevantes de su trabajo, junto con las premisas conceptuales que guiaron de distintas maneras sus investigaciones y la crítica de fuentes documentales que subyace en sus aportaciones, en particular aquellas que se refieren al tipo de lectura de las imágenes propuesta por la autora.

Una de las premisas básicas consiste en señalar que las dictaduras no sólo ejercieron un terrorismo de Estado y una represión brutal sobre el

\section{()(1) $\$$}


conjunto de los ciudadanos, sino que también llevaron a cabo labores de inteligencia para persuadir y buscar el consenso y el apoyo de una parte significativa de la población. Esta labor que buscaba la construcción de una hegemonía en términos gramscianos puede documentarse en el hecho de que los años más intensos de la represión, los cuales se produjeron entre 1976 y 1979, también representan de manera paradójica el lapso de un mayor consenso y aceptación del régimen entre amplios sectores de la sociedad.

Una parte importante de estas labores de inteligencia pasó por una estrategia de comunicación y propaganda diseñada por departamentos de psicología y otras instancias de asesoría del régimen, las cuales buscaban la aniquilación y la destrucción del enemigo, como parte de una labor simbólica que complementaba el trabajo de represión llevado a cabo por los agentes del orden y sus grupos clandestinos en el campo y las ciudades.

De esta forma, la autora documenta la manera en que al conocido "Plan Cóndor" -orquestado y operado por las dictaduras en aquellos añosse le añadió un proyecto equivalente, el cual se difundió en los distintos medios de comunicación utilizando en el nuevo rompecabezas a las imágenes fotográficas como uno de sus vehículos de mayor contundencia y eficacia para intentar moldear cierto tipo de conductas y buscar la homogeneización de los comportamientos colectivos. ${ }^{5}$

Al respecto, CG explica de qué manera el gradual control de los medios -que comenzó con la ridiculización de la figura de la presidenta Estela Martínez de Perón (Isabel) y su gabinete en algunas revistas y periódicos- fue construyendo progresivamente la percepción pública sobre la inevitabilidad de un golpe de Estado, anhelado por sectores sociales muy amplios como respuesta y solución al caos.

Otros historiadores han insistido en que dichos sectores vieron la llegada de los militares como una opción transitoria y realista, tanto frente a los altísimos niveles de carestía e inflación cotidiana, como de cara al insoportable nivel de violencia pública alcanzado por los asesinatos orquestados por los grupos paramilitares vinculados al ministro López Rega y las ejecuciones y operativos implementados por la guerrilla urbana que poco a poco había dejado atrás el terreno de la negociación política para militarizar

${ }^{5}$ El Plan Cóndor coordinó todo tipo de operativos represivos de las dictaduras militares de Chile, Paraguay, Argentina, Uruguay, Bolivia y Brasil contra la disidencia política y con la asesoría y el apoyo de la Central de Inteligencia Americana, la CIA, en los años setenta (Nilson, 1988).

\section{()(1) $\$$}


completamente a sus cuadros (Larraquy, 2013). En este contexto, CG muestra cómo los militares argentinos tomaron en cuenta la cobertura mediática en torno al espectacular golpe de Estado del general Augusto Pinochet contra el presidente Salvador Allende en septiembre de 1973, que visibilizó todo tipo de detenciones y secuestros de ciudadanos inermes en los espacios públicos, lo mismo que el bombardeo e incendio del Palacio de la Moneda, el cual produjo de inmediato un escenario internacional adverso a los planes de la dictadura.

A contrapelo del caso chileno, las fuerzas armadas argentinas planificaron tres años después un golpe higiénico y aséptico, programado como una intervención quirúrgica, en la que el cambio de poder apenas fue percibido como la simple realización de un trámite administrativo en las páginas editoriales de los principales diarios, con la consecuente construcción de un modelo de "normalización" de la vida cotidiana que esta operación conlleva y que se traducía en una supuesta tranquilidad en todos los ámbitos de la vida pública y privada.

Es interesante constatar de qué manera este trabajo de editorialización de la fotografía, tanto en periódicos como en revistas, desempeñó un papel clave en esta labor normalizadora, que buscó incorporar de manera armónica la figura de los militares al paisaje social cotidiano.

Una vez producido el golpe en marzo de 1976, la estrategia mediática del régimen consistió en ocultar de manera sistemática los asesinatos y las violaciones a los derechos humanos de miles de disidentes, cuyo rostro e identidad fue negado en una operación planificada, que mostró de antemano el tipo de trato que dichas personas iban a recibir en los cientos de centros de detención y exterminio previamente dispuestos y organizados por los militares a lo largo del territorio argentino: De acuerdo con Gamarnik (2011a):

Para poder secuestrar, matar y torturar, era necesario convertir al otro en una cosa. Era necesario un tratamiento que evitase cualquier grado de empatía, de identificación, de ver al otro como un semejante. A los "elementos subversivos" no se les considera ciudadanos con derechos, ni actores políticos, ni hombres y mujeres con afectos ni familias. La represión que cae sobre ellos no puede tener ningún reparo moral. Se los trata como objetos, invisibilizados y aislados socialmente, cosificados. Se los deshumaniza y al negarles su humanidad se los transforma en seres que pueden ser matados, descartados, sin ningún tipo de derechos (p. 63).

\section{(ㄷ)(1) $(3$}


Al respecto y como un ejemplo representativo de esta tendencia, la autora analiza la portada de la revista Gente, correspondiente al 30 de diciembre de 1976, esto es, en el apogeo de la represión castrense. Dicha portada está ocupada casi en su totalidad, gracias a un encuadre vertical que fortalece su posicionamiento en la imagen, por una hermosa muchacha de tez blanca, con trenzas casi adolescentes y en bikini, sentada plácidamente en la arena de una playa con las manos descansando sobre sus muslos y observando seria y de frente al posible lector de la publicación, en un plano completo y en ángulo normal, lo que promueve la cercanía afectiva de los destinatarios de la imagen. A un lado puede verse el titular que anuncia la lectura de un "documento imprescindible": se trataba nada menos que de "la historia secreta de la guerrilla en Argentina”. En el lenguaje simbólico implícito en el código de la imagen, el cuerpo de la muchacha sustituía a los miles de cuerpos de los otros jóvenes guerrilleros desaparecidos, en una operación de frivolización y de banalización que la autora vincula a la famosa reflexión de la filósofa Hannah Arendt sobre estos temas. ${ }^{6}$

En el caso de la revista Gente cabe considerar que los hechos oscuros y subterráneos de una represión militar con una carga tanática fueron asociados y representados en la portada de la revista con una imagen que posee una carga erótica evidente. Como ya se señaló, uno de los mecanismos puestos en marcha por esta política editorial consistió en proyectar una imagen de "normalización" de la vida cotidiana que intentaba ocultar el lado oscuro de las cosas y construir un horizonte de evasión atractivo para el lector de clase media de este tipo de publicaciones.

De acuerdo con mi perspectiva, la antítesis de este ejercicio está representada por el conocido trabajo de León Ferrari, titulado Nosotros no sabíamos (1992), en el cual el artista plástico recoge 85 notas publicadas en la prensa argentina durante 1976 que se refieren de muy distintas maneras a la presencia del tema de la represión en el imaginario cotidiano de los argen-

${ }^{6}$ Es conocida la manera en que Arendt (2003) cubrió para la revista The New Yorker el juicio a Adolf Eichmann en Israel en 1961 y enfrentó diversas críticas cuando se opuso a los espacios mediáticos dominantes de la época, que proyectaban al oficial de la Gestapo con una carga amarillista y sensacionalista como una figura diabólica. A contrapelo de esta tendencia, la filósofa señaló que Eichmann no era un psicópata perverso de características excepcionales, sino un burócrata afiliado servilmente a un régimen, y que lo más inquietante del caso residía en el hecho de que la maldad formaba parte integral de la naturaleza humana y podía florecer en cualquier Estado autoritario. Uno de los conceptos en los que profundizó en varios de sus libros es precisamente el de la "banalización del mal".

\section{()(1) $\$$}


tinos. Así las cosas, lo que en Ferrari aparece como evidencia documental para cuestionar la justificación de una falta de información, en la revista en cuestión se convierte en un mecanismo de negación que oculta una realidad y la evade.

Para CG, la otra cara de esta estrategia mediática consistió en la operación de humanización de la figura de los represores, alrededor de los cuales se construyó editorialmente una aureola de padres de familia y funcionarios honestos y probos.

Conviene aclarar aquí que este tipo de construcciones mediáticas no representan una invención original de la dictadura en este tipo de asuntos, ya que estamos frente a un recurso editorial tan antiguo como la existencia de la propia prensa, y cuyo antecedente más relevante está representado por aquellas revistas ilustradas publicadas en ambos lados del Atlántico, desde la Berliner Illustrierte hasta el Paris Match, pasando por la célebre Life, que en la década de los veinte y los treinta del siglo pasado cubrieron para sus lectores reportajes gráficos muy amplios, en los que se pretendía acompañar al mandatario en turno, desde Joseph Stalin hasta Franklin D. Roosevelt, pasando por Adolfo Hitler y Benito Mussolini, durante un día de su vida cotidiana y acercar de esta manera a millones de lectores a lo que se suponía era el círculo íntimo del poder (Frizot, 1998).

En síntesis, CG documenta la forma en que la dictadura militar argentina diseñó y llevó a cabo una estrategia mediática de control que incluyó una planificación en torno a las maneras de abordar determinado tipo de temas y situaciones con otros gobiernos militares de la región y de qué manera la fotografía periodística representó una de las piezas angulares de este rompecabezas para legitimar los planes y las acciones del gobierno militar entre distintos sectores de la población civil.

$\mathrm{Al}$ respecto, considero que un momento paradigmático de esta divulgación de una imagen idílica del régimen está representado por la campaña oficial del mundial de futbol de 1978, en el que, bajo el lema de "Los argentinos somos derechos y humanos" el régimen convocó a todos los ciudadanos a "jugar de argentinos", denunció la supuesta existencia de un complot y una campaña internacional contra el país y buscó silenciar las denuncias amparado en la euforia nacionalista generada por el triunfo albiceleste en el mundial de futbol de 1978.

En mi opinión, la película La fiesta de todos, dirigida por Sergio Renán (1979) representa uno de los documentos visuales que retratan con mayor vigor aquel momento. En esta se proyecta la imagen de una Argentina "de pie frente

\section{(1)(1) $\$$}


al mundo", con un pueblo unido, alegre y solidario que disfruta del triunfo frente a las críticas y los comentarios adversos que provenían del exterior. ${ }^{7}$

Considero de gran importancia el hecho de subrayar la efectividad mediática de este y otros instrumentos del gobierno, que le generaron un apoyo y un consenso entre amplios sectores de la población. De acuerdo con Moreno (2014): "Sería un error creer que el golpe de Estado fue resistido por la sociedad. Fue aceptado, a veces con resignación, a veces con entusiasmo, por casi todas las fuerzas políticas y la Iglesia (sólo el movimiento sindical se expresó con dureza) y con alivio por el sector más poderoso del empresariado [...] Los medios de comunicación mayoritarios también apoyaron el golpe” (p. 154).

Hemos comentado en este apartado el trazo de algunas de las coordenadas del régimen visual implementado desde la perspectiva del régimen, guiados por la mirada siempre atenta de Gamarnik. En los siguientes apartados examinaremos algunos de los huecos y grietas por donde se filtró una serie de miradas alternas que permitieron un diagnóstico crítico en torno al poder y las maneras de interrogar este universo documental por parte de nuestra autora.

\section{LAS MADRES Y SUS ALIADOS}

Si hablamos de la lucha contra la dictadura militar, aparece un símbolo universal: las Madres de Plaza de Mayo, pero ¿qué fueron y qué son las Madres de Plaza de Mayo, sino fundamentalmente una imagen, una imagen fotográfica? Resulta imposible separar al símbolo político más alto de la lucha contra la dictadura de su imagen visual. Esos pañuelos blancos, esas figuras dolorosas rodeando la plaza son uno de los grandes aportes de los reporteros gráficos. Sin ellos, ese símbolo no se hubiera terminado de construir.

Roberto Gómez, director del diario Acción, en entrevista con Cora Gamarnik.

${ }^{7}$ En el filme, el discurso final de Félix Luna sintetiza el mensaje de la obra: "Estas multitudes delirantes, limpias, unánimes, es lo más parecido que he visto en mi vida a un pueblo maduro, realizado, vibrando con un sentimiento común, sin que nadie se sienta derrotado, marginado, y tal vez por primera vez en este país, sin que la alegría de algunos signifique la tristeza de otros."

\section{()(1) $\$$}


Las primeras denuncias de la represión y las desapariciones de personas corrieron a cargo de los propios familiares de las víctimas, los cuales se vincularon con una serie de grupos y asociaciones defensores de los derechos humanos, algunos de ellos fundados antes de la dictadura y otros creados durante la represión. Entre ellos, vale la pena destacar: la Liga Argentina por los Derechos del Hombre, el Servicio de Paz y Justicia (SerPaj), el Movimiento Ecuménico por los Derechos Humanos (MEDH), la Asamblea Permanente por los Derechos Humanos (APDH) y Familiares de Desaparecidos y Detenidos por Razones Políticas.

Sin embargo, el grupo que se convirtió con los años en el protagonista más relevante a nivel nacional e internacional fue el de las Madres de Plaza de Mayo, creado en el año de 1977.

Estudiar las representaciones fotográficas en torno a las Madres de Plaza de Mayo significa historizar una parte importante de la lucha por los derechos humanos de la Argentina reciente, pues este grupo constituye el sector crítico de la dictadura más influyente tanto a nivel nacional como internacional. CG muestra cómo una parte significativa de esta influencia fue conquistada por las propias Madres a partir de una alianza con fotógrafos locales y agencias internacionales que las fueron posicionando en los espacios públicos.

Al principio las Madres y los demás familiares de las personas secuestradas y desaparecidas buscaron información sobre su paradero en las propias oficinas del gobierno. Poco a poco fueron haciendo contactos entre ellos y llegó el momento en que tomaron la determinación de manifestarse en el espacio público más importante del país, la Plaza de Mayo, para reunirse y hacerse visibles (Gorini, 2006).

El régimen las reprimió desde un inicio. Ellas representaban la figura central sobre la que está basada toda estructura social, en su calidad de figuras maternas y de esta manera la estrategia oficial intentó descalificarlas y resignificarlas como "locas", buscando estigmatizarlas y tratando de restarle toda racionalidad a su discurso.

No se trató sólo de represión simbólica, ya que se produjo un hostigamiento permanente hacia ellas por parte de las fuerzas militares y policiacas legales y clandestinas, incluso algunas sufrieron secuestros y torturas y se las hizo desaparecer, como el caso del asesinato de su fundadora Azucena Villaflor y el de las monjas Alice Domon y Léonie Duquet. ${ }^{8}$ La presencia

${ }^{8}$ Este grupo fue secuestrado a principios de diciembre de 1977 por un grupo de tareas de la Escuela Mecánica de la Armada, torturadas en esta institución y arrojadas al mar con

\section{(이요}


pública de las Madres asumió una postura simbólica clave. Su denuncia permitió desde un inicio visibilizar la figura de los desaparecidos, tal como señala Gamarnik (2010):

Mientras la dictadura negaba la existencia de los desaparecidos, su presencia pública y mediática -en sí misma una denuncia- lo desmentía. Al doble ocultamiento, de los desaparecidos y de sus familiares buscándolos, se les opuso una doble visibilidad. Por un lado, las madres y otros familiares comenzaron a portar las fotos de sus hijos e hijas, esposos, mujeres, nietos y nietas, devolviéndoles un rostro, una identidad, una historia y un lazo social, volviendo visibles a quienes habían sido desaparecidos, es decir, ocultados a la vista social. Pero ellas mismas estaban invisibilizadas. Ahí es donde la acción de algunos fotorreporteros permitió ayudar a quebrar esta segunda invisibilización (p. 6).

Las Madres fueron obteniendo cada vez mayor reconocimiento internacional y comenzaron a posicionarse a nivel local cada vez con mayor fuerza a partir de 1979 .

La trayectoria mediática que siguió la proyección del grupo en la opinión pública puede observarse primero a nivel internacional y después en la propia Argentina, situando cada etapa en su contexto y retomando el testimonio y punto de vista de los fotógrafos que se acercaron a ellas y funcionaron, junto con algunos editores y representantes de agencias, como aliados estratégicos en esta lucha contra la represión y la censura militar.

En la búsqueda de crear estas condiciones de visibilidad fue determinante el propio proyecto del grupo, que en plena maduración de su proceso de identidad como sector de oposición utilizó el trabajo de los fotógrafos como una de sus armas fundamentales para posicionarse en la opinión pública.

Nora Cortiñas, presidenta de Madres de Plaza de Mayo-Línea Fundadora, señala en entrevista con Gamarnik (2010):

Las fotos sirvieron para identificarnos como grupo, siempre buscábamos que hubiera fotógrafos en nuestras actividades y llamábamos a los diarios para avisar de las cosas que íbamos a hacer [...] El rol de los fotógrafos ayudó to-

vida un par de semanas más tarde. En particular, una fotografía de las religiosas francesas tomada en la ESMA por los marinos fue utilizada públicamente por este sector para intentar adjudicar el secuestro al grupo de "montoneros". Para una revisión del caso y un análisis de la fotografía en cuestión, véase Feld (2012).

\section{(ㅇ)(1) $\$$}


talmente para la denuncia cuando no se podía poner en letras lo que el hecho representaba. Las imágenes de la represión en las calles, los milicos con los fusiles provocándonos, todo eso ayudó para que en el mundo entero se conociera el drama que se vivía. Nosotros siempre le estuvimos agradecidos a la prensa gráfica. Cada año en sus muestras iban poniendo como evolucionaba el tema de los derechos humanos (p. 8).

En la perspectiva de CG, es importante analizar las etapas de su trayectoria mediática y dentro de ello reconstruir el papel estratégico que desempeñó la fotografía para construir ciertas condiciones de visibilidad en la opinión pública, las cuales resultaron fundamentales para la elaboración de una memoria independiente de los circuitos del poder militar.

Para la autora, un primer éxito mediático está representado por la foto de Eduardo di Baia, de la agencia Associated Press, que fue publicada en varios medios internacionales y en la cual se muestra de frente en un encuadre horizontal y con un ángulo de picada moderada, en la que resalta en un plano medio, los rostros de varias mujeres desesperadas con pañuelos cubriéndoles la cabeza, gritando y gesticulando: "Cada una de ellas refleja con su gesto los sentimientos y actitudes por los que atravesaban. Llanto incontenible en un caso, ruego en el otro, grito y reclamos en el tercer caso y mirada tensa e inquisidora en el último" (Gamarnik, 2010, p. 5).

Se trata de varias de las Madres captadas en la Plaza San Martín durante la visita a Argentina del secretario del Departamento de Estado de Estados Unidos, Cyrus Vance, y que lograron el objetivo de llamar la atención del político y los periodistas que lo acompañaban. Fue una primera victoria contra la represión de la dictadura y la indiferencia de un sector amplio de la opinión pública, que mostró al grupo el camino a seguir en intervenciones futuras. ${ }^{9}$

El contexto para comprender la relevancia de esta fotografía es fundamental. La visita del político en 1977 marcó el inicio de una mayor presión del gobierno de James Carter para que los militares dieran permiso a algunas instancias internacionales para documentar in situ el tema de los derechos humanos. Esta lucha se prolongaría, como ya se mencionó, al año siguiente

${ }^{9}$ El video con el registro de este episodio se exhibe como parte de la propuesta del Museo de la Memoria de Rosario, uno de los más reconocidos del país. Para Rubén Chababo, director de dicho espacio en 2014, se trata de uno de los acontecimientos que más influyó en la construcción de una memoria sobre la dictadura (R. Chababo, comunicación personal, 1 de octubre de 2014).

\section{()(1) $\$$}


con la realización del mundial de futbol y culminaría en 1979 con la autorización oficial de Videla para la visita de la Comisión Interamericana de Derechos Humanos (Gorini, 2006).

Dicha comisión pudo revisar in situ miles de denuncias y entrevistar a un número muy amplio de personas que le permitieron elaborar un informe en el que se documentaron por primera vez más de 5000 denuncias por desapariciones, lo que representó un golpe internacional muy efectivo contra la dictadura. En la ONU se discutió el caso y se votó una declaración histórica, que calificó lo que ocurría en Argentina y otros países como la peor violación a los derechos humanos desde el Holocausto, mientras que en 1980 se otorgó el Premio Nobel de la Paz a Adolfo Pérez Esquivel, un personaje identificado con la lucha por los derechos humanos, fundador del SERPAJ y que había sufrido en carne propia secuestro, tortura y cautiverio por parte de los militares en agosto de 1977 por un lapso de catorce meses.

A partir de ese momento ya no resultó viable para la jerarquía militar seguir ignorando de manera sistemática la existencia de un plan global de represión. Pese a ello, continuaron los esfuerzos oficiales por minimizar la crudeza de una realidad cada vez más conocida a nivel internacional, y tuvieron que generarse otras condiciones y coyunturas para que la lucha por los derechos humanos ganara un poco más de terreno en el interior del país.

Como señala Novaro (2010), uno de los errores de cálculo político más notables de la dictadura consistió en el hecho de subestimar el cambio de paradigma en el contexto internacional, cada vez más favorable a mediados de los setenta a posicionar la lucha por los derechos humanos como una de las fuentes de legitimidad política y ética más importante de las democracias occidentales en su búsqueda de hegemonía frente al autoritarismo de la Unión Soviética. En tal contexto debe inscribirse la presión del gobierno de James Carter que fructificó con la autorización del general Videla -con la oposición de la marina y la fuerza aérea- a la visita de la CIDH en 1979.

En este contexto, CG ha seleccionado algunas de las imágenes más influyentes que posicionaron a las Madres a nivel internacional, leyendo las fotos a través de tres ejes fundamentales que la autora denomina de la siguiente manera: resistencia/voluntad-perseverancia/y tristeza-dolor (Gamarnik, 2010, p. 14).

Lejos de representar áreas diferentes, estos niveles temáticos se encuentran presentes en cada una de las imágenes y lo más significativo consiste en la vinculación de los iconos con sus contextos respectivos y los testimonios de los propios fotógrafos.

\section{()(1) $(2$}


Para los fines de este artículo, vamos a elegir sólo tres de las imágenes del universo seleccionado por la autora, a manera de muestra. Todas fueron tomadas en el año de 1982, en el declive de una dictadura desgastada y con fisuras internas y en plena efervescencia de la protesta ciudadana que volvió a expresarse en las calles y fue reprimida por los cuerpos policiacos y la gendarmería. Se trata del reposicionamiento de las imágenes en el espacio de la opinión pública, factor que contribuyó, como ya se ha señalado, a la construcción de una transición democrática que se incrementaría con la aventura fallida de los militares en las Malvinas en abril de ese año.

La primera fotografía es de la autoría del fotógrafo Eduardo Longoni y se refiere a la "Marcha por la vida", del 2 de octubre de 1982. En ella aparecen dos mujeres en la parte inferior izquierda de la imagen, en un primer plano, protegiendo sus propios cuerpos con la manta que han desplegado durante la protesta y resistiendo la embestida de un policía que luce montado en un caballo, en un plano completo que permite apreciar su gestualidad y la actitud agresiva con la que agrede a las mujeres.

La posición del fotógrafo es muy riesgosa, pues está casi en la misma línea de las mujeres, justo enfrente del corcel (fotografía 1).

El testimonio de Longoni en Cerolini (2006) es fundamental para contextualizar la imagen:

Las Madres de la Plaza de Mayo, con los pañuelos y las marcas de los desaparecidos en las arrugas de las caras, peleaban en los despachos oficiales, en sus casas, en las calles. El día de la "Marcha por la vida" querían llegar a su plaza, pero un poder en retirada quería impedirlo. En la esquina de Diagonal Norte y Piedras se enfrentaron con un cartel y con su dignidad contra la policía montada. En medio de esa escaramuza recuerdo que pensé lo contrario de lo que Susan Sontag sostenía sobre la fotografía de prensa, quien la calificaba esencialmente como un acto de no intervención. Necesité estar a tiro de los palos de los policías, casi bajo los hocicos humeantes de los caballos. Allí donde estaban ellas, tratando de hacer pie. Sólo de esa cercanía podía surgir una foto que mostrara el dolor, la impotencia, una imagen de la rabia (p. 181).

La cita no tiene desperdicio. Entrelaza un conjunto de argumentos en los que el autor de la imagen no sólo describe la foto y los personajes, sino que los llena de contenidos políticos y culturales. Es al mismo tiempo una declaración de principios, en la que el profesional se rebela contra la visión del fotógrafo considerado como un simple "cazador" de imágenes que no in-

\section{(이이 $(3$}




\section{SECUENCIA}

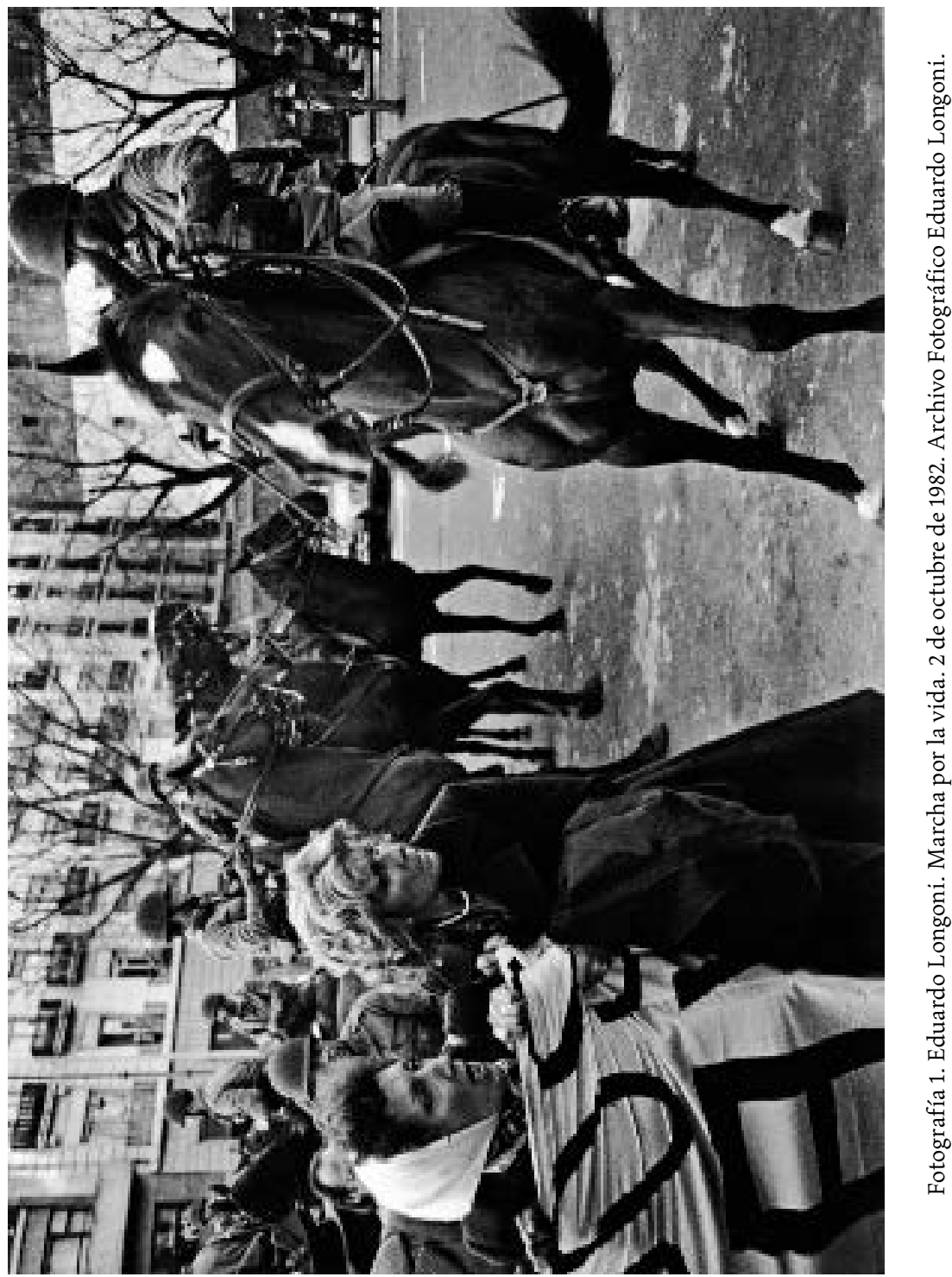

\section{(우(1) $(3$}


terviene en el objeto retratado, tal como lo pregonaba Cartier-Bresson para aquellos años y asume en cambio un papel mucho más activo y solidario.

La cercanía con las mujeres "bajo los hocicos humeantes" de los caballos le hace sufrir los mismos riesgos y temer por su integridad personal. Es otro más de los ciudadanos que capta desde abajo la figura amenazante de los policías montados. ${ }^{10}$

Con esto, Longoni logra proyectar a los lectores de la fotografía el mismo ángulo visual desde el que están percibiendo la escena las propias Madres.

Una segunda imagen captada en un encuadre horizontal corresponde a Daniel García y fue cubierta durante la "Marcha de la resistencia", del 10 de diciembre de 1982. Un cordón policiaco impide el ingreso de las Madres a la plaza. El fotógrafo estaba colocado detrás del cordón y captó de frente y en plano medio los rostros de dos de las mujeres que luchaban desesperadamente por avanzar, con las bocas abiertas por la tensión y mostrando de manera un poco grotesca una parte de la dentadura, en una mueca de dolor que refleja de alguna manera su frustración, coraje e impotencia (fotografía 2).

El espejo de al lado reproduce una parte del forcejeo de todo el grupo y el rostro de una de ellas se refleja en forma bastante curiosa, como si chocara con su propia cabeza, lo que incrementa la fuerza de una imagen bizarra y le confiere un cierto halo de rareza, con la presencia surrealista de un enorme hocico de uno de los caballos, captado de perfil y en primer plano. ${ }^{11} \mathrm{El}$ nombre de la mujer es Lilia Orfanó y el testimonio de García, recogido por la investigadora, informa al lector que a partir de esta imagen se fortaleció una alianza entre la Madre y el profesional de la lente como hijo simbólico y aliado estratégico. ${ }^{12}$

${ }^{10} \mathrm{Al}$ mismo tiempo, en entrevista con el autor de este artículo, Longoni considera que esta fotografía es el resultado de un "error", en la medida en que el fotógrafo debe conservar una distancia óptima para la realización de su trabajo y en aquella ocasión la perdió y quedó a la merced de la agresión de los militares. Tal sería la diferencia entre la óptica de un profesional de la lente y la del militante (Castillo, 2014).

${ }^{11}$ Puede considerarse que el efecto del espejo que refleja la cabeza de la Madre también duplica su dolor, construyendo así una metáfora de las condiciones de sufrimiento del grupo en aquella coyuntura (C. Gamarnik. comunicación personal, 15 de agosto de 2014).

${ }^{12}$ En aquellos primeros meses se fue construyendo una alianza entre algunas de las Madres con los fotógrafos de las agencias. Entre otras cosas, los fotógrafos las cubrían en sus rondas y luego les proporcionaban imágenes que las Madres enviaban al exterior. Tal fue el caso del fotógrafo Eduardo Longoni y Nora Cortiñas. En esta peculiar relación, los fotógrafos cuidaban de las Madres y estas, a su vez, se quedaban preocupadas por los profesionales de la lente y les hablaban por teléfono para verificar que hubieran llegado a sus casas u oficinas sin contratiempos (E. Longoni, comunicación personal, 16 de septiembre de 2014).

\section{()(1) $(3$}




\section{SECUENCIA}

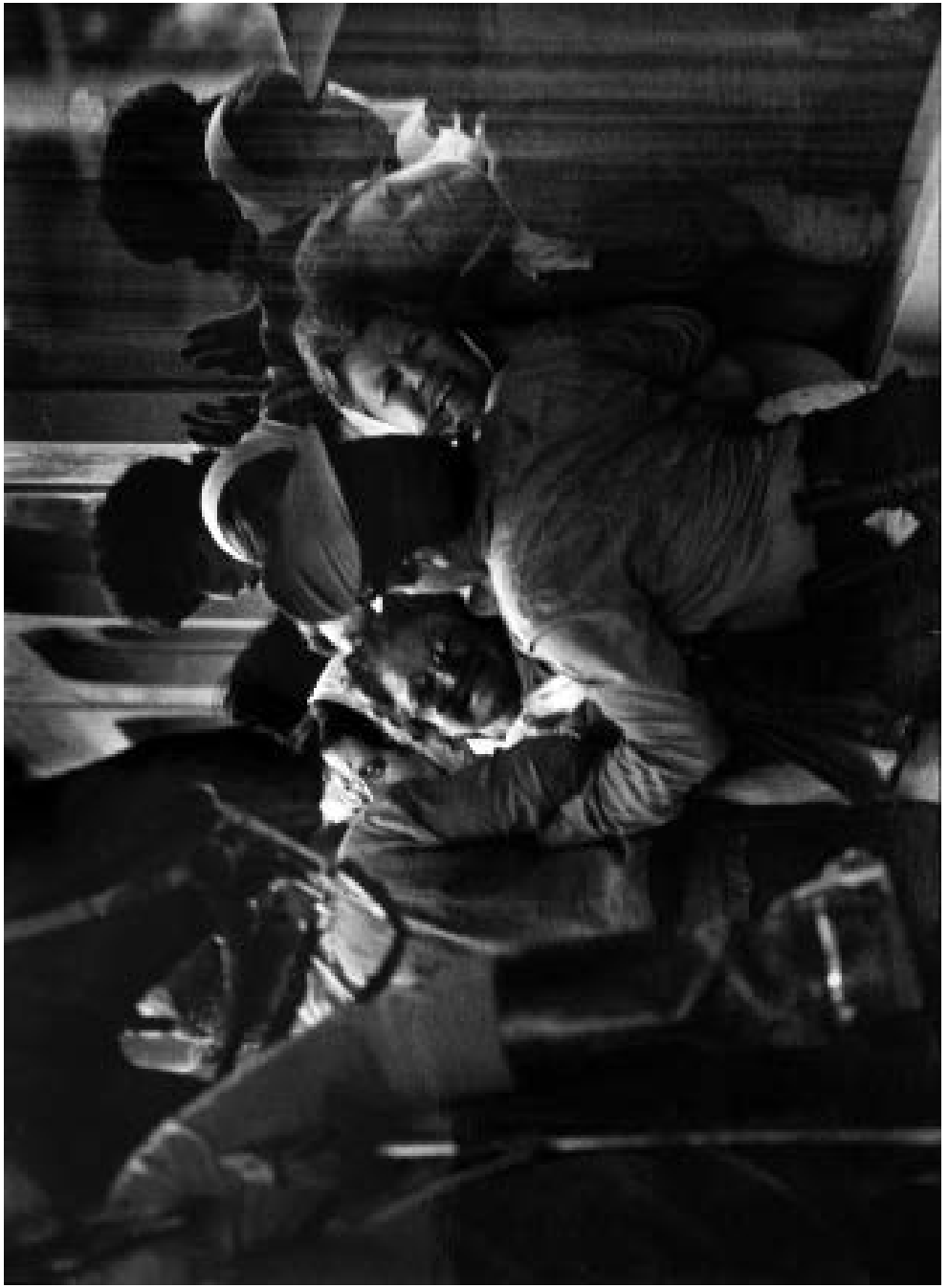

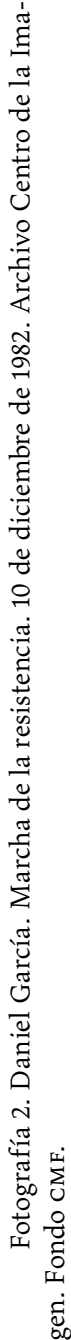

\section{(ㄷ)(1) (8)}

Atribución-NoComercial 4.0

internacional (CC BY-NC 4.0) 
Algunas semanas más tarde, García elaboró un reportaje en el que contó la historia de la mujer y sus dos hijos secuestrados por los militares y retrató la fachada del frente de su casa, la cual fue pintada por agentes de la dictadura con la leyenda: "Lidia y Lucas subversivos".

Una tercera imagen se ha convertido en uno de los iconos más representativos de la lucha de las Madres y constituye un paradigma de la lectura de género para cierto tipo de imágenes documentales. La autora es Adriana Lestido, quien captó la imagen en Avellaneda, en aquel año axial de 1982. Se trata de un primer plano de una mujer y una pequeña unidas en la arenga de la protesta con sus brazos extendidos y los puños de sus manos izquierdas cerrados (Blanca Freitas y su hija Mariela, reclamando por la desaparición de su hermano, Avelino Freitas), proyectando ambas una figura simétrica dotada de una visualidad muy atractiva. Los pañuelos blancos y los carteles de la parte posterior, en los que pueden leerse los reclamos por la presentación de algunas personas secuestradas por el ejército nos remiten al entorno de la revuelta.

Como señala CG, la metáfora está presente en el acento en la unión entre la mujer y la niña, la ausencia del padre y la presencia de la pequeña, que continua con la lucha, con el gesto expresivo de ambas, unidas en un grito desesperado de protesta (fotografía 3).

La propia fotógrafa contextualiza y aporta información para leer este trabajo como una referencia importante para el desarrollo de su propia trayectoria:

Al empezar el acto una nena que estaba con su mamá se puso a llorar y los fotógrafos que cubrían la marcha se abalanzaron a fotografiarla. A mí me dio como un pudor fotografiar a la niña llorando, pero en un momento la madre la alzó, la nena dejó de llorar y ahí hice la foto. Es una Madre de Plaza de Mayo atípica, porque pide por el marido, no por el hijo, y la nena está pidiendo por el padre, ese hombre ausente que de algún modo ha sido el eje central de toda mi obra (Gamarnik, 2010, p. 45).

La premisa de CG en la selección de estas imágenes asume que este tipo de lenguaje posicionó ciertas condiciones de visibilidad a un grupo de personas que comenzaron denunciando su tragedia personal y gradualmente se fueron construyendo como sujetos sociales de transformación democrática, al ser las portadoras de una demanda clave: la reivindicación de un Estado de derecho en plena dictadura. Así pues, el halo de prestigio hacia las Madres, proyectado y difundido a todos niveles por los fotógrafos también se exten-

\section{()(1) $\$$}




\section{SECUENCIA}

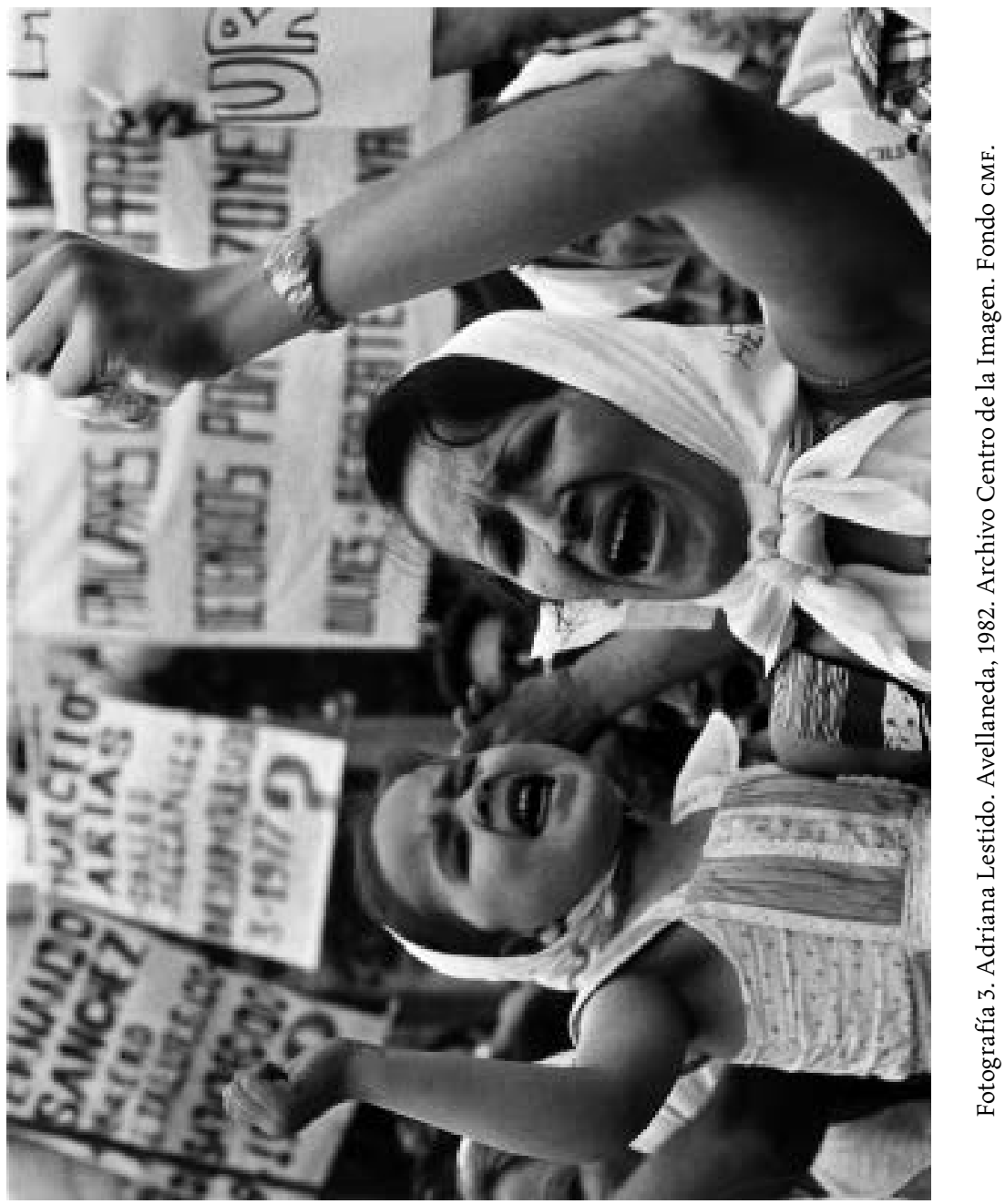

\section{(ㄷ)(1) (8)}


dió hacia la labor de estos y legitimó su trabajo como sujetos y protagonistas del cambio en Argentina y América Latina.

La labor hermeneútica de CG nos ha mostrado en este apartado de qué manera el trabajo de algunos de estos fotógrafos en torno a este grupo constituye un ejemplo muy significativo de la eficacia simbólica de este tipo de espacios en la lucha por la democracia y la restauración de un Estado de derecho. A pesar de constituir una minoría respecto de la cantidad total de los familiares de los desaparecidos, la labor mediática focalizada en sus historias de vida y sus acciones simbólicas de protesta permitió una difusión pública de sus derechos y reivindicaciones. A manera de complemento, cabe considerar que la historia de la lucha de las Madres no puede ser percibida en forma homogénea y lineal y por el contrario ha estado sujeta a múltiples contradicciones a lo largo de su desarrollo y construcción en los años duros de la dictadura y también en el constante desgaste de las distintas etapas de la democracia. Uno de los más significativos ocurrió en 1986 y tuvo repercusiones importantes en el uso de las fotografías. El grupo liderado por Hebe de Bonafini decidió darle un significado universal a la lucha por los derechos humanos y dejó de individualizar los rasgos de las fotos de los desaparecidos y suprimió los nombres de cada uno para que un número mayor de madres pudiera identificarse con el símbolo del movimiento.

Esta pugna entre la reivindicación del carácter universal de la fotografía como símbolo versus la reivindicación de la lectura de las fotografías como índice y pista para el seguimiento de los rasgos concretos se vincula al contenido de proyectos políticos distintos, que proponen lecturas y usos del universo fotográfico diferentes (Longoni, 2010). Pude constatar la vigencia de las diferencias entre ambos proyectos en la ronda de las Madres en la Plaza de Mayo correspondiente al jueves 7 de agosto de 2014. Por un lado, Bonafini y su grupo marcharon con una manta en la que podía leerse: "Hasta la victoria siempre, queridos hijos" y corearon consignas contra los militares, pero sin exhibir ninguna imagen (fotografía 4). De manera simultánea, pero a unos treinta metros de distancia, las madres del grupo encabezado por la ya mencionada Nora Cortiñas llevaban una manta que decía: "30 mil detenidos-desaparecidos. PRESENTE”. Ellas sí portaban diversas fotografías de sus hijos desaparecidos y para remarcar la identidad de cada uno de ellos iban pronunciando en voz alta sus nombres (fotografía 5).

Los dos grupos se ignoraron y abandonaron la plaza por lugares diferentes ante la perplejidad de algunos turistas que llevaron a cabo el registro fotográfico de todo el ritual, sin comprender el significado de la ausencia de

\section{()(1) $(2$}




\section{SECUENCIA}

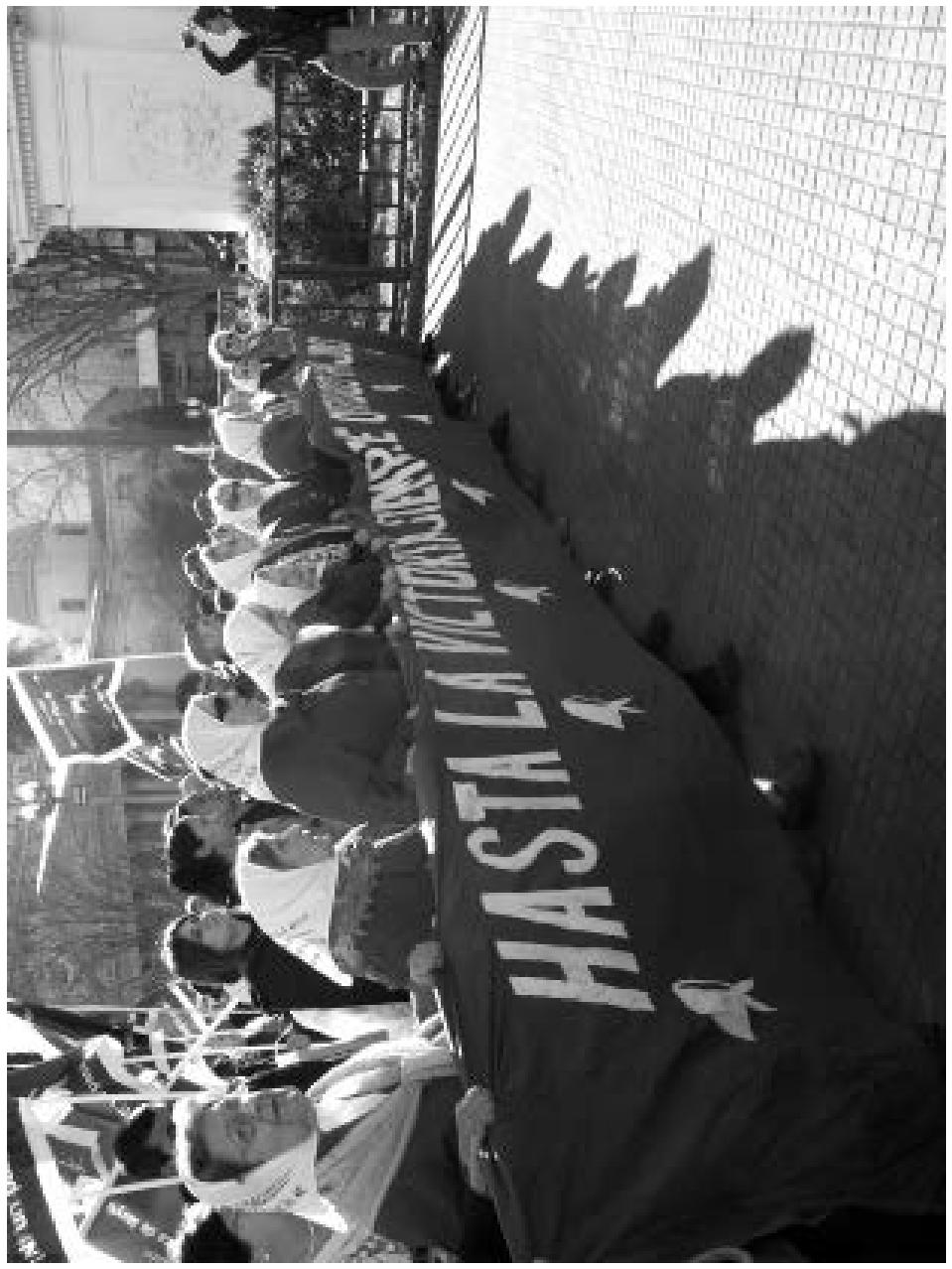

ชั

츤

a

च

is

tซ

$\sum 0$

o

बे

政

좀

츨

도

艺

을

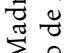

$\sum 0$

w

.

चี

准

\&

官

范

ช

चี

운

ปี

远

+ 뭉

莺莺 节

$80 \pi$

० $\Xi$

言 完荙

\section{(c) (1)\$}




\section{SECUENCIA}

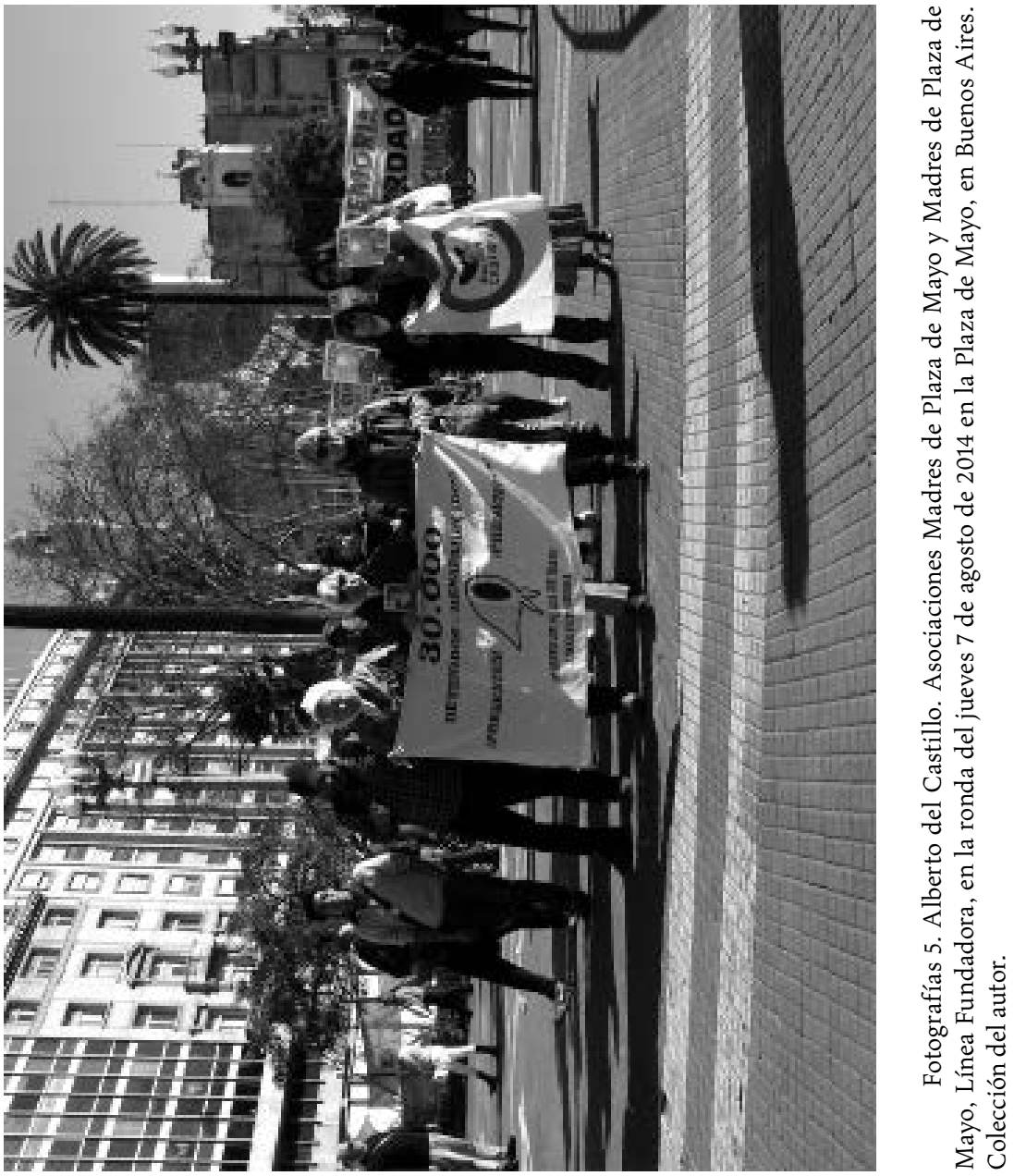

\section{(ㄷ)(1) $(8$}


todo tipo de comunicación entre las mujeres. ${ }^{13}$ Se trata de todo un síntoma de la distancia generada entre ambos grupos a 30 años de la ruptura ya mencionada. Es interesante constatar el grado de conciencia en torno al poder de las imágenes de parte de uno de sus creadores más importantes, como puede verse en el epígrafe de este apartado. Pese a todo, y a pesar del desgaste que ha menguado su legitimidad entre algunos sectores, resulta muy contundente la enorme importancia del trabajo de los fotógrafos y los editores en la construcción del icono más poderoso de la lucha civil contra la dictadura.

La perduración de este símbolo universal en la lucha de movimientos sociales posteriores y en la construcción de una memoria colectiva nacional e internacional, lo ha resignificado y lo ha incorporado a otras luchas democráticas, tanto en la propia Argentina como en el resto de América Latina en los años recientes.

\section{UNA EXPOSICIÓN PIONERA}

No todos los fotoperiodistas se alinearon al diseño de control implementado por el régimen. Algunos se opusieron al modelo y encontraron distintas rutas y fisuras para plantear sus puntos de vista, tanto en las páginas de los diarios y revistas como en otros espacios de la vida pública.

En este contexto de censura ejercida por los militares, CG ha estudiado de qué manera una de las principales armas de editores y fotógrafos consistió en la disposición de una mirada irónica que buscó ridiculizar a la dictadura. Dicha ironía, que implica el ejercicio de un sentido del humor ácido y crítico permitió en ocasiones trasgredir una realidad sin violentar las reglas de la censura, que estaba diseñada y pensada para acotar los textos escritos. ${ }^{14}$

${ }^{13}$ El otro punto a destacar tiene que ver con la institucionalización del grupo de Bonafini y la incorporación de su sección en el 2005 a las políticas estatales del gobierno de Néstor Kirchner, tendencia que se fue incrementando en las gestiones posteriores de Cristina Fernández de Kirchner. Lo anterior permitió un acceso al presupuesto que consolidó su proyecto, pero al mismo tiempo las expuso al desgaste político y las colocó en un contexto de mayor vulnerabilidad, al verse involucradas tanto en confusos episodios financieros como en la necesidad de avalar polémicas decisiones del Estado.

${ }^{14}$ Puede pensarse en el ejercicio de la ironía como un punto de partida clave para la realización de una lectura crítica de los regímenes autoritarios, tanto en un sentido político como ético (Rorty, 1966).

\section{()(1) $\$$}


Si en los primeros años del régimen resultaba imposible la publicación de imágenes con este contenido crítico, fue a partir de finales de 1981 que las condiciones comenzaron a cambiar y un nuevo contexto, no exento de represión, permitió la difusión de algunas de estas fotografías a través de carteles, libros y exposiciones. Así, la investigadora describe la forma en que los propios fotógrafos se encargaron de enfrentar la política mediática gubernamental de control de las imágenes. Esta lucha desigual fue llevada a cabo por algunos profesionales a título individual y a partir de 1981 contó con la complicidad de otros colegas que comenzaron a editorializar sus propios trabajos, con la cobertura de asociaciones públicas creadas al calor de las coyunturas, como el Grupo de Reporteros Gráficos (GRG). Este grupo organizó la Primera Muestra de Periodismo Gráfico en diciembre de 1981, en la que se incluyeron algunas fotografías críticas en un contexto visual de imágenes "políticamente correctas" (Gamarnik, 2013).

Es importante detenerse en la forma en que la autora ha podido reconstruir el contenido de la exposición, cuya estrategia estuvo orientada a la presentación de un núcleo "duro" de imágenes contestatarias junto con una periferia de fotografías comunes y corrientes, inocuas e inofensivas, para equilibrar el contenido general de la exposición y hacerla viable frente a la censura de la dictadura. ${ }^{15}$

Este episodio permitió aglutinar a lo mejor del fotoperiodismo crítico en plena dictadura. De esta manera, la presentación de la mencionada muestra en Buenos Aires del 3 al 16 de diciembre de 1981 contó con la colaboración de 70 profesionales de la lente, la exhibición de 200 fotografías y la participación nada desdeñable de cerca de 5000 personas.

CG ha subrayado la importancia del acontecimiento, que representó una ruptura con la voluntad homogeneizadora de la dictadura y permitió al público acercarse a la diversidad de miradas que mostraron la cara oscura de la realidad argentina hasta entonces minimizada o censurada por los militares. Es muy importante la reconstrucción de este episodio, así como los dos siguientes que crecieron en convocatoria y se realizaron en 1982 y 1983,

${ }^{15} \mathrm{Al}$ respecto, véase la entrevista de la autora con el fotógrafo Aldo Amura, uno de los organizadores de la exposición Gamarnik (2013). De acuerdo con estos planteamientos, las fotografías más críticas representaron los efectos sociales y económicos de la dictadura, el surgimiento de nuevas fuerzas disidentes entre los que sobresale el grupo de las Madres y la mirada irónica que ridiculizaba a algunos integrantes de la junta cívico-militar. La recuperación de este tipo de testimonios orales permite a la autora una lectura más amplia de todo el episodio.

\section{()(1) $\$$}


en pleno declive del régimen, porque permiten analizar la propuesta de un lenguaje visual distinto al convencional que predominaba en diarios y revistas de la época.

A manera de complemento, cabe señalar que este tipo de foros vinculan a Argentina con lo que ya estaba ocurriendo en otros países cercanos con la celebración de los coloquios latinoamericanos en México y Cuba desde finales de los setenta del siglo pasado, en los que comenzaron a coexistir propuestas estéticas y documentales.

Por otro lado, también permiten reflexionar en torno a conceptos como la censura y, sobre todo, la autocensura que también influyó en la definición del evento, y que se manifestó entre otras cosas en la ausencia de algunos colegas temerosos de la represión en sus medios de trabajo, o en la omisión de algunas imágenes que podrían haber resultado ofensivas para el régimen, de acuerdo con la propia percepción de los protagonistas.

Resulta muy significativa la paradoja señalada por la autora en torno a la aparente contradicción de la existencia de una mayor visibilidad pública de los trabajos de los fotógrafos en 1981 y al mismo tiempo el registro de un incremento de la represión hacia el gremio por parte de los militares. De acuerdo con esta visión de las cosas, los años de la represión clandestina bajaron en intensidad a principios de los ochenta, pero la presencia mucho más activa de los fotógrafos ligados a la prensa documentó el ejercicio de la represión en los espacios públicos y permitió la adquisición de un mayor grado de conciencia de lo que estaba ocurriendo en Argentina por parte de sectores más amplios de la población.

Esta es una premisa que resalta la importancia del ejercicio de un cierto tipo de fotografía vinculada a la opinión pública en la construcción de una transición democrática en este país en aquellos años. La ausencia de registros fotográficos en torno a los secuestros y la represión en los centros clandestinos contrasta así con la documentación de la violencia ejercida por los militares en los espacios públicos.

Aunado a lo anterior, la exposición constituye un valioso espacio y un interesante corpus documental creado, protegido y difundido por los propios fotógrafos en un contexto de censura y control por parte de los militares, que permite también abrir un espacio para pensar en las características del modelo "realista" imperante en la fotografía documental y periodística en Latinoamérica en el último cuarto del siglo pasado.

En efecto, dicho modelo se expresa en frases de los propios fotógrafos organizadores del evento, que argumentaban cuestiones como que el objeti-

\section{()(1) $(9$}


vo más importante de la muestra era el de "dar testimonio de la realidad", o que la presentación de las fotografías debería consistir en "imágenes directas, sin trucos ni falsificaciones" (Gamarnik, 2013, pp. 72-75). ${ }^{16}$

Cabe recordar aquí que la fotografía incorporó esta pretensión de dar cuenta de una manera directa de la realidad desde sus inicios a mediados del siglo xIx y posteriormente la continuó ejerciendo en el fotoperiodismo a lo largo de todo el siglo pasado. Una buena parte de la credibilidad documental de la fotografía se basa en esta creencia y forma parte la ética de la profesión que compartía este grupo de profesionales de la lente en la Argentina de aquellos años. ${ }^{17}$ Los itinerarios son muy heterogéneos y pasan por distintos ámbitos de la vida cotidiana y las expresiones políticas y culturales no reconocidos por el régimen.

A manera de muestra, vale la pena detenerse en tres de las fotografías seleccionadas por la autora que resaltan el trazo de su mirada: la de Carlos Villoldo sobre la ronda de las Madres en la Plaza de Mayo, en el año de 1981, que con un encuadre horizontal y en un plano general permite la lectura amplia y completa del escenario, con detalle para apreciar a los distintos personajes y el entorno, da cuenta en un ángulo de picada moderada de una numerosa protesta pacífica y ordenada, dibujando un círculo alrededor de la Pirámide, frente a la Casa Rosada. Se trata de un lugar altamente simbólico, que después adquiriría fama internacional como parte de uno de los rituales políticos más representativos de la lucha por los derechos humanos en América Latina.

Otra, es el retrato de un par de niñas sonrientes que con sus vestidos usados y deshilachados miran de perfil a la cámara junto a un vagón de tren en el que puede leerse la palabra: "Argentina". Esta es de la autoría de Rafael Calviño.

Y, finalmente, la irónica imagen de Eduardo Longoni, sobre los obispos retratados en la vía pública bajo el letrero de "Astros", con un mensaje implícito de crítica hacia la jerarquía católica en los años de la dictadura.

Las tres proyectan la realidad de un país distinto al imaginado por los militares.

${ }^{16}$ La autora cita folletos y otros documentos escritos a máquina en los que se divulgaban este tipo de planteamientos para la exposición.

${ }^{17}$ Una reflexión interesante sobre estos conceptos y su vinculación con los espacios públicos puede verse en Monroy (2008) y Mraz (2008).

\section{()ㅜ(1) $\$$}


En la primera fotografía se asoma con toda su fuerza el grupo disidente más relevante de aquellos años, cuya simple presencia contradecía el discurso del régimen.

En la segunda puede verse una representación de la niñez marginada distinta al modelo oficial, la cual construye una metáfora que combina de manera armónica la parte estética con la documental (fotografía 6).

Esta imagen puede compararse, tanto por su propuesta artística como por su contenido visual, con la foto icónica del fotógrafo mexicano Rodrigo Moya que también utilizó el recurso de los vagones de ferrocarril para construir retratos tomados al paso y referirse de esa manera a la realidad latinoamericana de la década de los sesenta del siglo pasado. Si bien ambos fotógrafos no se conocieron, la combinación armoniosa de sus contendidos estéticos y documentales sirve para ejemplificar la existencia de vasos comunicantes en la historia de la fotografía latinoamericana durante esta etapa (Castillo, 2012, pp. 37-40) (fotografía 7).

La tercera representa un vigoroso y fresco retrato callejero que rompe de manera radical con una visión tradicional de la jerarquía católica. Lograda con un encuadre vertical y utilizando un primer plano que permite apreciar la gestualidad pétrea de los protagonistas de la imagen, la mirada juguetona del fotógrafo contrasta la solemnidad de los obispos captados en un plano americano, enfundados en sus sotanas con las manos entrelazadas a la altura de sus vientres, como si estuvieran oficiando en el atrio de una iglesia, pero posando en realidad junto a uno de los teatros de espectáculos frívolos más famosos del centro de Buenos Aires, con el anuncio de un espectáculo de teatro de revista popular en la parte posterior de la imagen.

El propio título de la marquesina con la palabra "Astros" parece referirse de manera irónica a estos personajes, considerados por sus propios feligreses como los representantes de Dios en la tierra. De hecho, en esta foto se ridiculiza el orden de lo sagrado al situar a sus protagonistas en el mundo de la picaresca urbana bonaerense de la época.

El peculiar circuito de esta imagen la llevó de su captura en el contexto de las agencias a su exhibición en la primera exposición gráfica de los fotoperiodistas. La férrea censura castrense no permitió, en un primer momento, la circulación de la imagen en la prensa, pero no pudo impedir el contacto y la recepción directa de miles de espectadores y asistentes a este espacio público, ávidos de encontrar imágenes alternas a la monotemática propuesta del fotoperiodismo oficial. Monseñor Juan Carlos Aramburu (extrema derecha) es un personaje clave para analizar el vínculo de la alta jerarquía católica con

\section{(1)(1) $\$$}




\section{SECUENCIA}

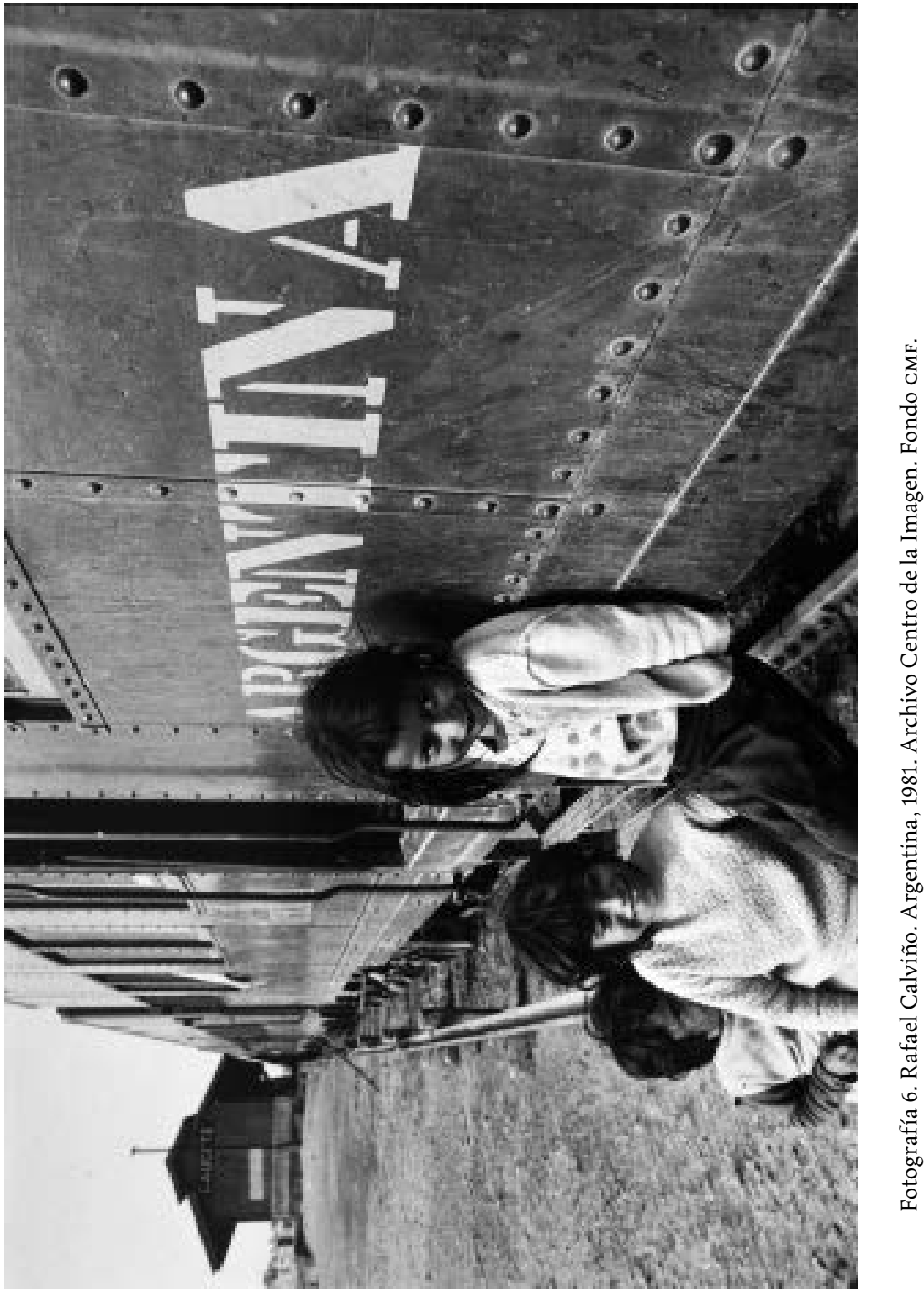

\section{(우(1) $(3$}




\section{SECUENCIA}

Secuencia, ISSN 0186-0348, núm. 96, septiembre-diciembre de 2016, pp. 226-277

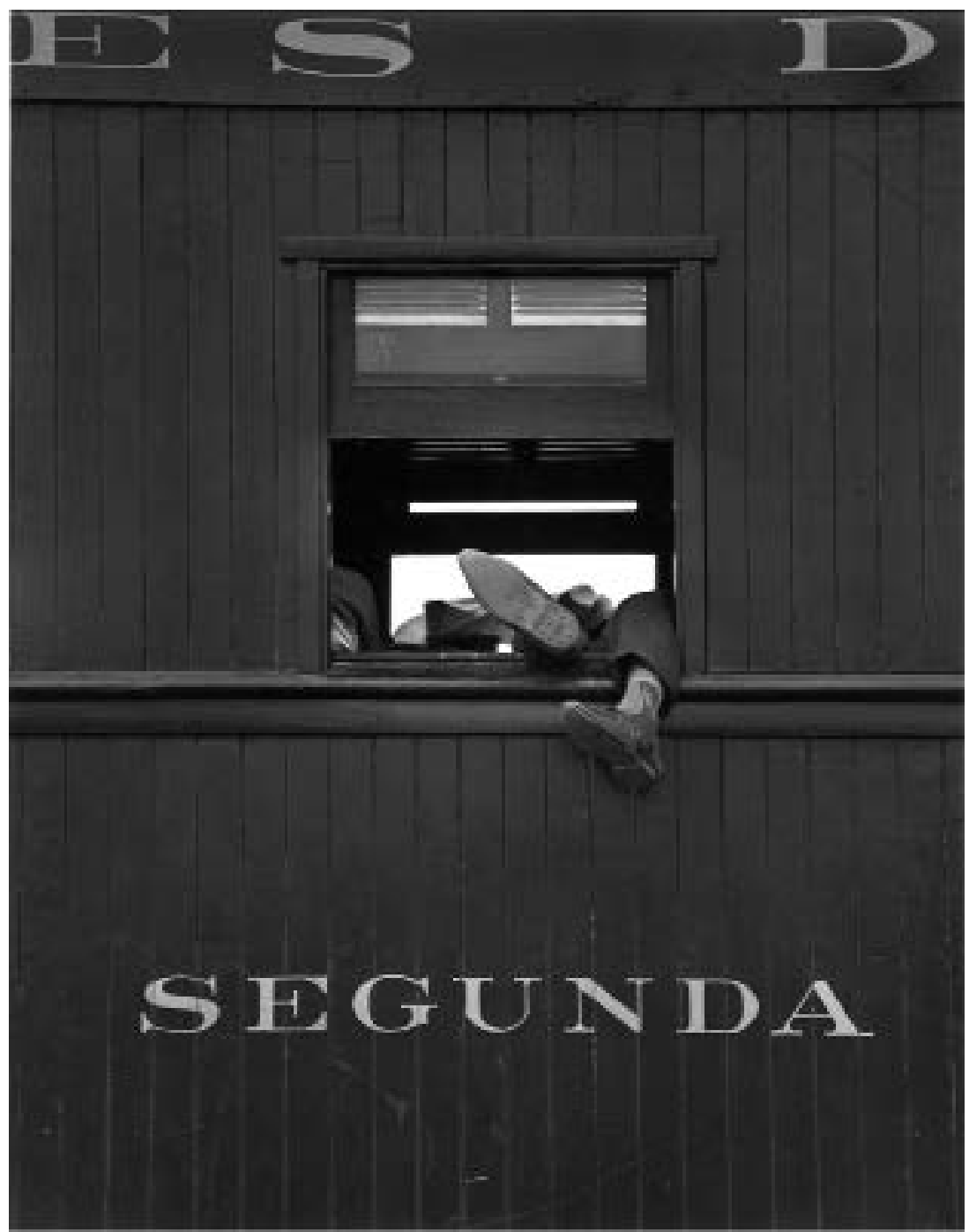

Fotografía 7. Rodrigo Moya. "Segunda”, México, 1967. Archivo Fotográfico Rodrigo Moya.

\section{(ㄷ)(1) $\$$}


la dictadura. Ordenado arzobispo de Buenos Aires en 1975 y cardenal a partir de 1976, fue un estrecho defensor y colaborador de los militares, con los que posó en diversas ocasiones (fotografía 8).

Es interesante considerar la forma en que la investigadora fue reconstruyendo las piezas de una exposición que ya sólo existe de manera fragmentada en el imaginario de algunos de sus protagonistas. Con esos pequeños hilos, CG fue recuperando contextos y trazando pinceladas que un par de décadas después se convirtieron en referencias relevantes para re-pensar uno de los episodios más importantes de la historia de la fotografía documental en los años de la dictadura. La recuperación de los testimonios visuales y la crítica de los discursos orales, vinculados en una dialéctica compleja que va mucho más allá del registro y pasa por una reinvención del pasado. Una de las escasas fotografías de la propia muestra da cuenta de algunos fragmentos de la obra expuesta. Tomados ligeramente de lado aparecen algunos de los fotógrafos integrantes de la exposición en un plano americano, en una línea diagonal, posando junto a la pared en la que están expuestas algunas de sus obras de manera muy sencilla, con modestas marialuisas y fijadas con clavos y tachuelas en tres niveles o hileras. Esta "fotografía de las fotografías", tomada con un encuadre horizontal y en una picada moderada por Guillermo Loiácono, uno de los fotógrafos participantes, permitió a la investigadora develar la lógica de la exposición, desentrañar y explicar algunas de las referencias centrales que rodearon a la misma. ${ }^{18}$

Con lo anterior me refiero a la dialéctica que se establece entre la memoria y la imagen a 30 años de distancia. Más que un simple recordatorio estricto del pasado, el testimonio reinventa aquí un escenario a partir de las premisas del presente. Por ello, lo más importante para una investigación de esta naturaleza reside en las cuestiones simbólicas y no la pretensión anacrónica de fidelidad a toda costa con el pasado.

A partir de lo anterior, la autora identifica el surgimiento de un nuevo fotoperiodismo en la Argentina de los sesenta como parte de un "nuevo clima”, el cual se inició en las páginas de las revistas ilustradas, continuó su formación a lo largo de la década de los setenta, incluyó el surgimiento de la primera agencia independiente como fue Servicios de Información Gráfica

${ }^{18}$ El fotógrafo e investigador Julio Menajovsky ha rescatado el archivo fotográfico de Loiácono para ponerlo a la consulta en el Archivo Nacional de la Memoria. A contrapelo de la historia oficial, la aguda e inteligente mirada de Loiácono constituye una de las referencias documentales más importantes para develar el lado oscuro de la dictadura.

\section{(이요}




\section{SECUENCIA}

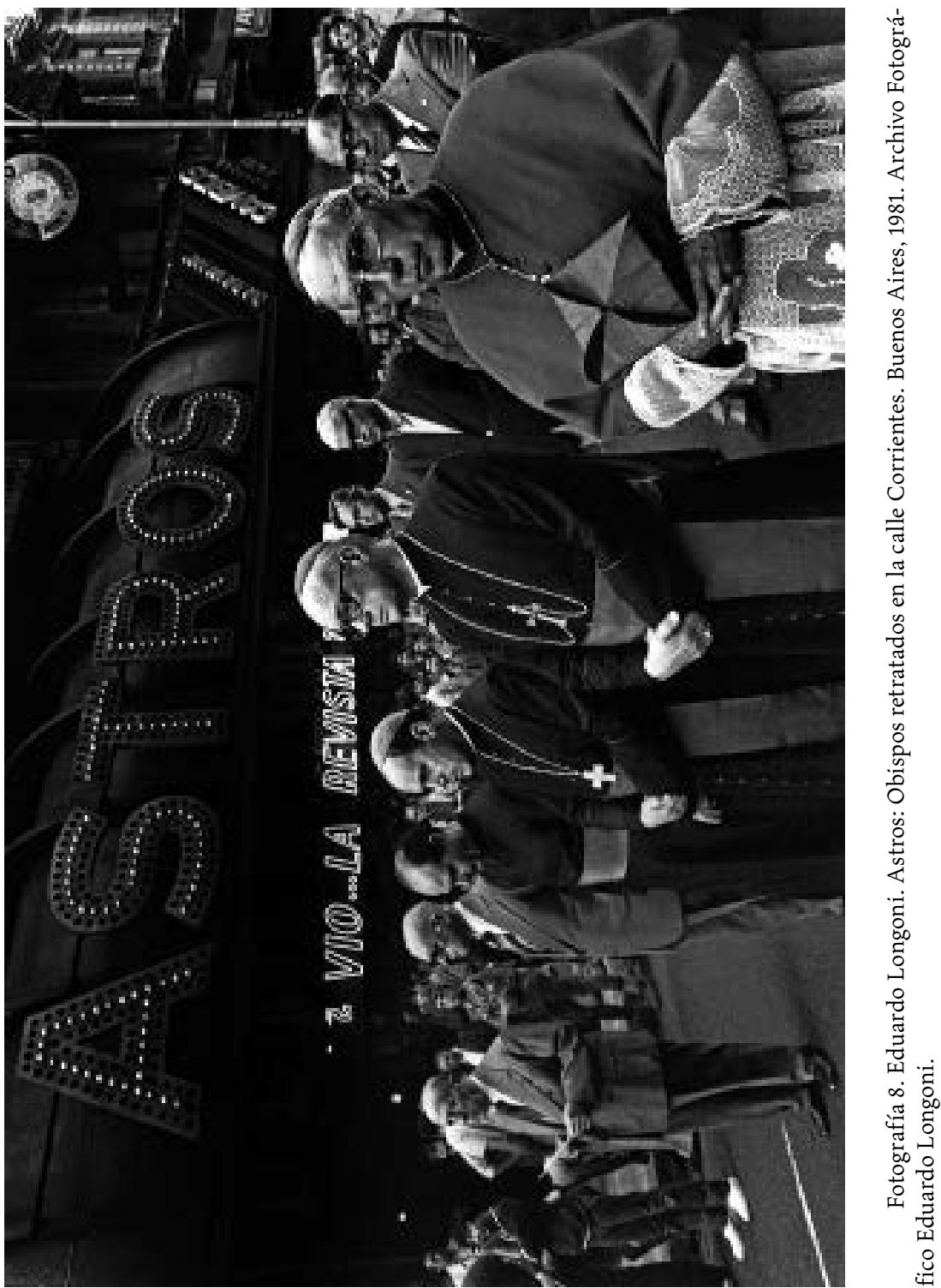

\section{(ㄷ)(1) $(8$}


Latinoamericana (sIGLA) y fue violentamente interrumpido con el golpe militar de 1976, hasta iniciar una lenta recuperación en los inicios de los ochenta:

Estos nuevos medios y agencias alentaron y permitieron la llegada a la fotografía periodística de una nueva camada de fotógrafos, que renovaba las formas y condiciones de trabajo que tenían hasta entonces en los medios masivos y comerciales. En algunos casos, su doble rol de militantes y fotógrafos, su vinculación con los hechos y su mirada política de aquello que fotografiaban, creó también como resultado una fotografía de nuevo tipo (Gamarnik, 2011c, p. 70).

En este contexto, resulta interesante cotejar este planteamiento con el concepto de "Nuevo fotoperiodismo mexicano", acuñado por el investigador John Mraz (Mraz y Arnal, 1996). En dicho libro, este autor se refiere al surgimiento de nuevos editores y fotógrafos en el México de finales de los setenta del siglo pasado, que construyeron nuevas miradas críticas en la opinión pública, antes impensables en el régimen autoritario encabezado por el Partido Revolucionario Institucional (PRI), en el país azteca, por lo que realizaron una contribución clave para el proceso de la transición democrática mexicana del último cuarto del siglo pasado. Esta nueva mirada de los fotoperiodistas, que también utilizaron la ironía y el sentido del humor desde una perspectiva crítica para ridiculizar a la clase política, o que desarrollaron una lectura política de la vida cotidiana e incorporaron una lectura de género para hacer visible públicamente a la figura de la mujer, entre otros indicios y pistas culturales, propios de aquella generación post 68 en toda América Latina, pudo expresarse con fuerza en la opinión pública en aquel país, mientras que en la Argentina de los años de plomo hay que rastrearla en las exposiciones organizadas por los propios fotógrafos y hay que leerla de manera oblicua en los diarios y revistas ilustradas de la época. Todos estos elementos permiten pensar en una historia más amplia de los fotoperiodistas como sujetos activos y protagonistas de cambios políticos y culturales en América Latina, más allá de sus evidentes particularidades.

Al respecto, pueden verse dos muestras de esta versión mexicana de renovación en el campo del fotoperiodismo a cargo del fotógrafo Marco Antonio Cruz, las cuales presentan una visión muy original en torno a los cuerpos policiacos y una lectura irónica en torno a Fidel Velázquez, el longevo líder de la Central de Trabajadores de México, totalmente cooptada por el Estado mexicano durante varias décadas (Fotografía 9 y 10).

\section{()(1) $(2$}




\section{SECUENCIA}

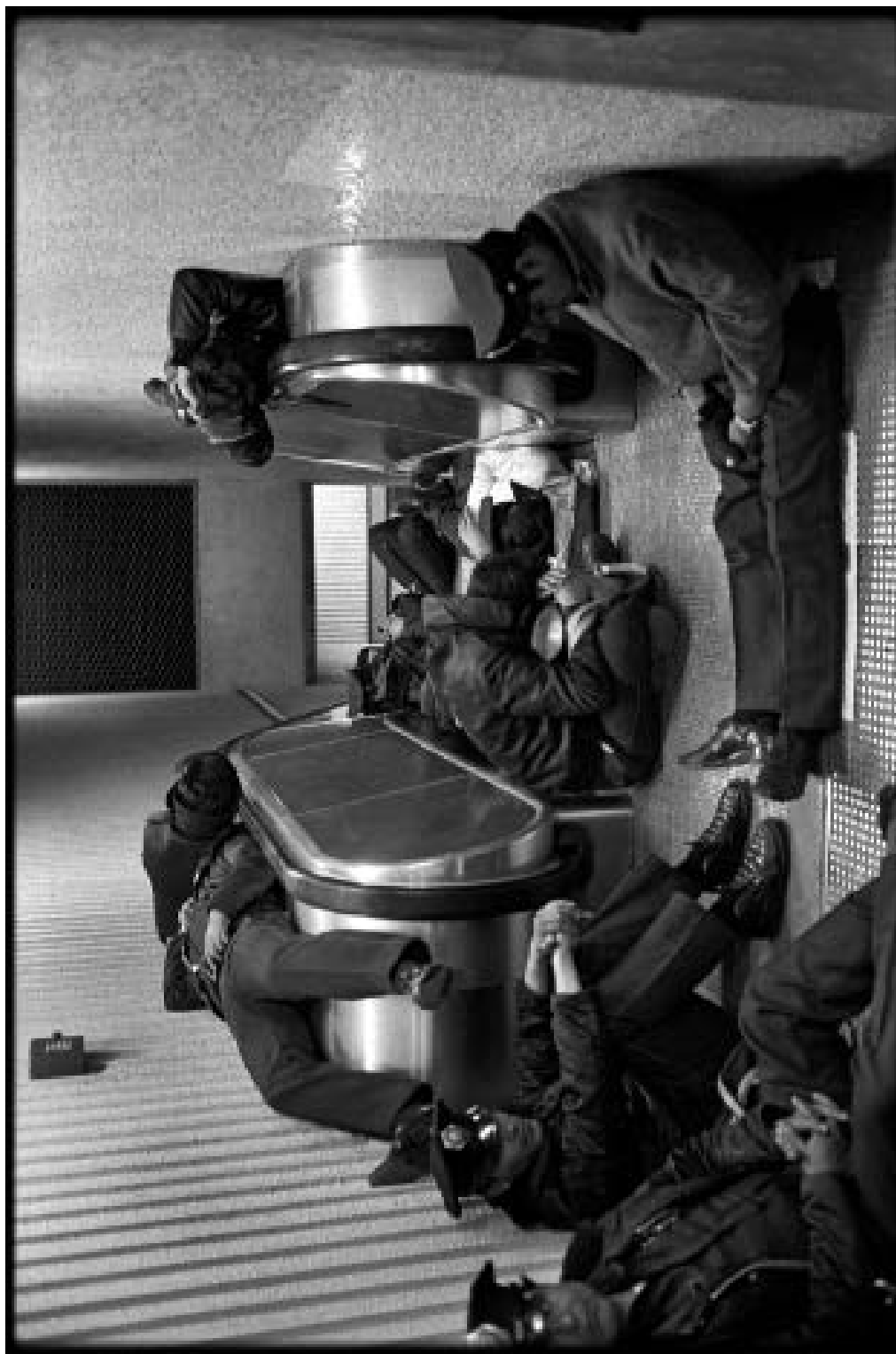

年

\section{(ㅇ)(1) 8}

Atribución-NoComercial 4.0

internacional (CC BY-NC 4.0) 


$$
\text { a }
$$




\section{LAS MALVINAS SON ARGENTINAS (Y LOS DESAPARECIDOS TAMBIÉN)}

"Las Malvinas son argentinas... y los desaparecidos también”, así rezaba un cartel que portaba una de las Madres en aquella terrible coyuntura en la que los militares recuperaron efímeramente las famosas islas, para beneplácito de una multitud que festejó el episodio en plena Plaza de Mayo, en abril de 1982 (fotografía 11).

Un lector distraído podría pensar que este apartado no tiene nada que ver con la línea de argumentación de los apartados anteriores, ligados a la percepción sobre la temática de la relación entre la fotografía, la memoria y los desaparecidos. Sin embargo, Gamarnik (2011b) nos aclarara que el debate en torno a las Malvinas en Argentina pasó por una serie de puntos estructurales que fueron mucho más allá de una anacrónica reivindicación territorial o de la reivindicación de un nacionalismo trasnochado:

Las Islas Malvinas no representan en Argentina sólo un reclamo territorial. Tambien son en sí mismas uno de los símbolos de la Nación alrededor del cual se disputan múltiples significados. Mientras que antes de la guerra las islas eran un fuerte reclamo ligado a una causa nacional y popular, pasaron a ser, durante el desarrollo de dicha guerra, el símbolo de una supuesta unidad nacional para luego transformarse en el símbolo de la vergüenza y la derrota para algunos, en tanto para otros fueron el doloroso paso con el cual pudo recuperarse la democracia en Argentina (p. 1).

Cabe decir entonces que el propio perfil de la transición democrática en Argentina y la creación de ciertas condiciones que generaron la posibilidad de revisar de manera crítica el pasado reciente y enjuiciar y encarcelar a algunos de los responsables de la represión de años anteriores tiene que ver con este episodio crucial, materia de reflexión fundamental para la democracia argentina reciente y que la diferencía en este punto respecto de lo que han podido hacer en el tema otras democracias que han elegido caminos y modelos distintos para la revisión de sus pasados autoritarios, como la brasileña, la chilena, la mexicana, la española y la sudafricana, con logros y resultados mucho más acotados (Jelin y Longoni, 2005).

Con esto no pretendemos sobredimensionar el análisis de CG en torno al modelo argentino e invalidar a los otros. Lo que queremos subrayar es la estrecha relación que guardan los límites y los alcances de esta revisión del

\section{()(1) $(9$}




\section{SECUENCIA}

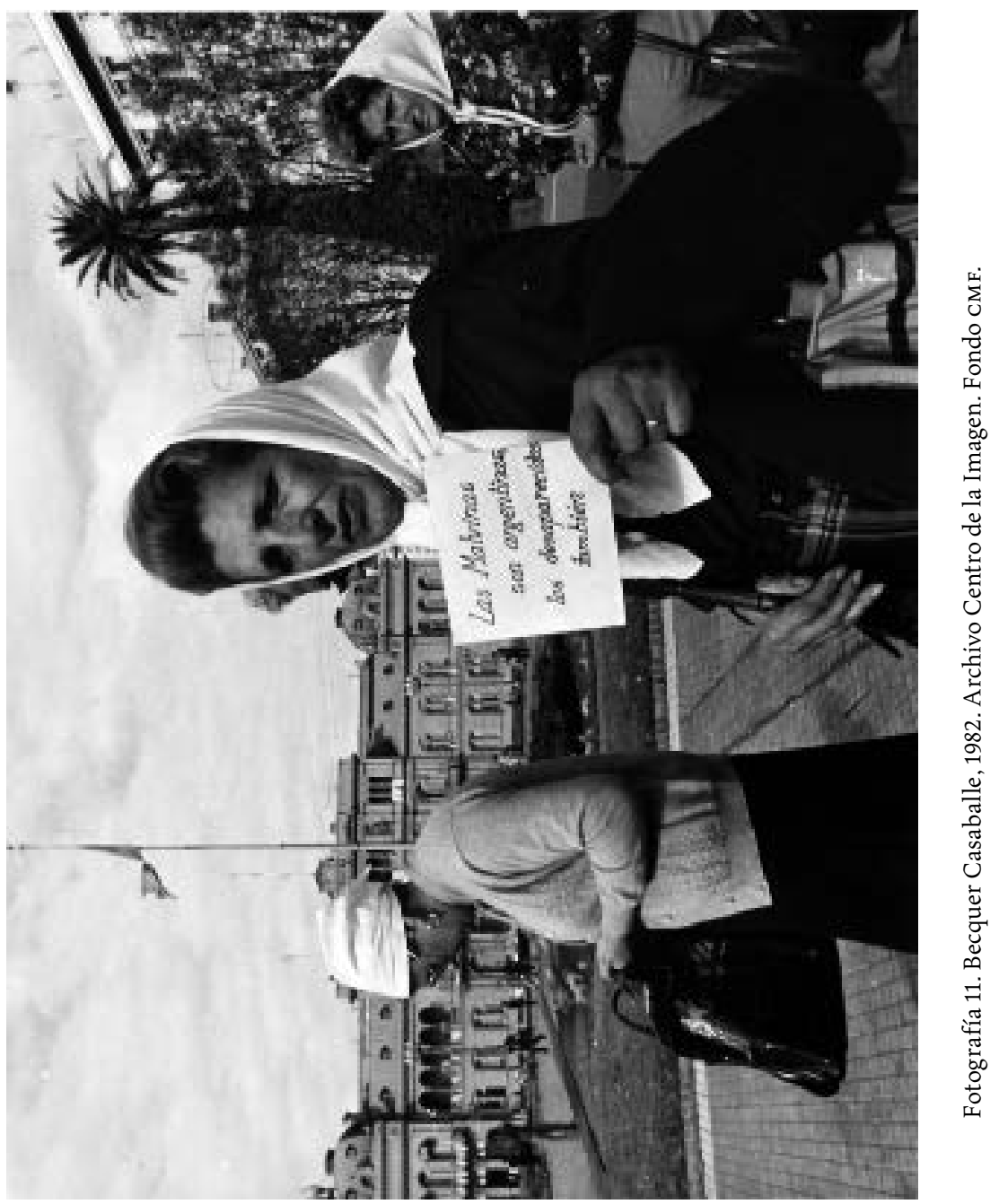

\section{(ㄷ)(1) $(8$}


pasado con las vicisitudes concretas del contexto histórico de cada país y por supuesto analizar el uso de las imágenes en dichos procesos como elementos importantes que han incidido en las distintas visiones del mundo y cuyo papel no puede reducirse a meras ilustraciones de los hechos. Por todo lo anterior, una revisión de mirada de la autora en torno a la cobertura fotoperiodística sobre el episodio de las Malvinas resulta de una gran importancia para reflexionar sobre los usos de las imágenes en esta revisión del pasado. $\mathrm{Al}$ respecto, CG no aborda la cobertura de la guerra propiamente dicha, sino que se centra en un par de imágenes icónicas que representaron a nivel internacional el momento de la recuperación argentina sobre las islas.

Se trata de las famosas fotos de Rafael Wollman tomadas el 2 de abril de 1983. Ambas imágenes están tomadas con un encuadre horizontal y en planos completos, que permiten revisar con nitidez toda la escena. En la primera puede verse a soldados del ejército inglés tendidos pecho tierra en la cuneta de una carretera, y en la segunda, tomada de frente, se ve una hilera de soldados con los brazos y las manos abiertas en alto, bajo las órdenes de un soldado del ejército argentino y en una condición inequívoca de rendición.

En ambos casos la cercanía del fotógrafo con los episodios evidencia la confianza castrense depositada en su trabajo, ya que se trata de operativos y maniobras muy relevantes que sólo podrían haber sido captadas con esa familiaridad por profesionales de la lente con el visto bueno del ejército triunfador.

En un trabajo de reconstrucción que puede entenderse como una "biografía de una imagen", Mauad (2011), retoma el testimonio del fotógrafo y otros testigos, analiza su acervo fotográfico para explorar secuencias y revisa el contenido de las distintas revistas y diarios que la publicaron, analizando con ello las condiciones de producción de la fotografía, el itinerario de la misma, la circulación y divulgación a nivel nacional e internacional, con efectos y resonancias muy distintas en lugares diferentes del planeta. ${ }^{19}$

De acuerdo con la versión de la autora, Wollman había creado a finales de 1982 la agencia Imagen Latinoamericana (ILA) con sus colegas Eduardo Bottaro, Tito La Penna y Silvio Zuccheri, todos ellos recientemente despedidos de la revista Gente en una operación de reducción de costos. Como parte

${ }^{19}$ Una lógica de trabajo muy similar es la que subyace en mi texto: "Las mujeres de X'oyep. La historia detrás de la fotografía" (2013) , en la que analizo las condiciones de registro de la fotografía icónica más influyente del zapatismo a cargo de Pedro Valtierra en 1998, revisando también las condiciones de recepción y difusión de la misma y partiendo de conceptos y categorías muy similares a las que despliega Gamarnik en su artículo sobre Malvinas.

\section{()ㅜ(1) 3}


de su nuevo trabajo para la agencia, el profesional viajó a las Malvinas en marzo de 1982 para realizar un reportaje fotográfico al estilo de la revista National Geographic sobre el paisaje, la flora, la fauna y la población de las islas y vender las imágenes a la agencia francesa Gamma. Así las cosas, la intervención militar argentina en Malvinas lo sorprendió en plena realización de su trabajo periodístico. Tanto Rex Hunt, el gobernador británico de las islas primero, como después los militares argentinos le brindaron facilidades para realizar su trabajo (uno en atención a su calidad de periodista acreditado como tal para la realización del reportaje y los otros por su nacionalidad argentina, que los hizo suponer que había viajado con ellos en uno de los barcos). De esta manera llevó a cabo el registro periodístico del operativo militar denominado "Rosario" aquella mañana del 2 de abril.

El testimonio del reportero, recogido por Gamarnik (2012), resulta clave para reconstruir el sentido de las imágenes:

Mi salvoconducto principal era hablar castellano y que ellos pensaran que, de alguna manera, por algo estaba yo ahí, que no vine en su barco, pero vine en el de al lado, en un Hércules... y yo traté y logré pasar desapercibido. No me engolosiné. De la foto de la rendición tengo dos cuadritos, de la foto de los ingleses en el piso también tengo dos cuadritos, no tengo veinte. Como todos estaban ocupados, todos tenían una función Imagínate: ¡Se estaban rindiendo los ingleses con las manos en alto! No me iban a preguntar: ¿Y vos quien sos? Si alguien me miraba dos veces, yo me iba a otro lado (p. 34).

Al igual que en la anterior cita del fotógrafo Eduardo Longoni, en esta, Wollman no sólo contextualiza los hechos, sino que brinda información muy relevante en torno a la lógica de trabajo de los fotorreporteros de la época, su visión del mundo y su forma de entender el oficio, en este caso bajo la metáfora ya mencionada del reportero como "cazador" de imágenes que mide cada uno de sus disparos, utiliza la cámara a cuentagotas y debe pasar desapercibido. Como ya se señaló, se trata de todo un plan de trabajo definido magistralmente por el fotógrafo Cartier-Bresson en sus razonamientos en torno al llamado "instante decisivo", que orientaron el trabajo de los fotoperiodistas durante una parte importante del siglo pasado.

Conviene razonar aquí en que Wollman no era el único fotógrafo en las islas aquel 2 de abril, sino que, como bien señala CG, había otros reporteros, periodistas e incluso soldados con cámaras de diverso tipo. Sin embargo, sólo las de Wollman lograron sintetizar y recrear la situación reuniendo las

\section{(이요}


condiciones técnicas y estéticas idóneas para obtener dicha condensación. Más allá de la fortuna del "instante decisivo" se impone aquí un proceso de trabajo con una trayectoria y un bagaje profesionales que han construido un ojo especializado para retratar este tipo de situaciones con una intención periodística. Los contactos profesionales con la agencia y la circulación internacional de las imágenes hicieron el resto.

En la narración de la autora, el fotógrafo pudo salir de las islas el 3 de abril con otros reporteros gráficos enviados por unas horas por los militares y logró vender el material a la agencia Gamma y a la editorial Atlántida. Los primeros quince días del mes de abril de aquel año de 1983 las dos fotografías de Wollman fueron desplegadas en los principales diarios y revistas a nivel internacional. El encuadre mediático fue contundente, se trataba de una prueba documental precisa sobre la humillación sufrida por el ejército inglés a manos de los soldados argentinos, en el contexto del declive del poderío político y militar británico, que el imperio venía arrastrando a lo largo de la segunda mitad del siglo $\mathrm{xx}$.

Tal es la lectura, destacada como botón de muestra por la autora, del diario Daily Mail, que con el titular de "Surrender" muestra la fotografía de los soldados en el suelo, o la del periódico L'Espresso, que elige la imagen de los militares con los brazos arriba en señal de rendición y cabecea con el título: "Mani in alto, Inghilterra!". Se creaba así en el imaginario internacional la visión de un imperio decadente y vencido por un país latinoamericano en los confines del sur del mundo.

Los historiadores han documentado, por un lado, el apoyo de una parte de la población al operativo dirigido por los militares, con todo y ovaciones de la multitud al dictador Galtieri en la Plaza de Mayo y la indignación que produjo este episodio tanto en el gobierno como en amplios sectores de la población en Inglaterra y la rapidez con la que actuó su primer ministra Margaret Thatcher para recuperar militarmente las islas.

Una oleada de patriotismo sacudió ambos países y fue utilizada de inmediato por sus gobernantes y sus aparatos mediáticos, con resultados completamente diferentes que produjeron secuelas y consecuencias muy distintas en cada caso. Por lo que respecta a los militares argentinos, la derrota provocó su descrédito total entre la población, impidió la continuación de su proyecto y aceleró el regreso de la democracia con menos trabas e imposiciones por parte de la cúpula castrense. Gamarnik (2012) razona en torno al uso y la circulación de estas fotografías como elementos que incidieron en la dinámica misma de los hechos:

\section{()(1) $(3$}


Nuestra hipótesis es que las fotos no fueron inocuas, que las respuestas, tanto simbólicas como materiales de Inglaterra frente al desembarco argentino, tomaron en cuenta el significado de esas imágenes a nivel mundial y la necesidad de desplegar una rápida respuesta para contrarrestarlas. Indudablemente la guerra fue producto de las profundas causas históricas que atravesaron los dos países en pugna, pero estas fotos de carácter excepcional actuaron en estos primeros momentos como catalizadores de distintos usos, interpretaciones y apropiaciones (p. 25).

La reflexión de la autora retoma el concepto ya mencionado de "vehículos de la memoria" de Jelin, según el cual algunos objetos no sólo representan el pasado, sino que lo incorporan performativamente. Tal sería el caso del uso de estas fotografías, las cuales, desde la perspectiva de CG pueden ser consideradas como instrumentos privilegiados en la construcción de sentido y de significados históricos, toda vez que contradijeron de manera directa el plan original de los militares de llevar a cabo una especie de intervención quirúrgica simbólica en Malvinas, contundente, pero no humillante, hacia Inglaterra y que diera lugar a una inmediata negociación política, con la intermediación positiva de Estados Unidos.

Al respecto, es interesante pensar en el hecho de que la fotografía diseñada por el gobierno militar para anunciar al mundo la recuperación de las Malvinas fue una imagen que de acuerdo a Gamarnik probablemente fue tomada en las instalaciones de la Escuela Mecánica de la Armada, la EsMA, el centro de detención, tortura y desaparición más emblemático de la dictadura. En dicha foto varios soldados argentinos izaban el lábaro patrio, en una referencia visual muy cercana a la famosa fotografía de Joe Rosenthal de los marinos estadunidenses en Iwo Jima, Japón, en 1945.

Aquel es uno de los episodios más famosos de la historia de la fotografía documental y periodística. Cabe recordar que la famosa foto tomada por Rosenthal el 23 de febrero de 1945 obtuvo el premio Pullitzer. Posteriormente se demostró que la foto fue posada y el fotógrafo diseñó toda la puesta en escena. El punto es relevante, pues ha dado lugar a toda una discusión sobre las características y el perfil de la fotografía documental, llegándose al consenso entre los historiadores en el sentido de que no existe ninguna fotografía espontánea o neutral.

Como señala la propia autora, por una de las ironías tan características de este tipo de historias, la fotografía ordenada por los militares argentinos no tuvo el efecto deseado y pasó desapercibida en aquellos días, mientras que

\section{()(1) $(9$}


las inesperadas y no programadas fotos de Wollman se convirtieron con el tiempo en una de las referencias más importantes del episodio. Como resulta evidente, la maquinaria de guerra comandada por la Thatcher se hubiera orquestado de igual manera, con fotos o sin ellas, pues sus razones de Estado obedecían a necesidades más profundas y a factores más complejos. Sin embargo, la rápida circulación de un par de fotografías imprevistas le proporcionó un rostro concreto a la intervención argentina y fomentaron la rápida identificación de vencedores y vencidos con los sujetos reales de una puesta en escena que tenía más nexos con la realidad que con la representación teatral:

El carácter indicial de la fotografía le otorgaba a estas imágenes su valor de prueba. Lo que allí se veía necesariamente había sucedido. Estas fotos eran la prueba de la rendición de los ingleses, pero tenían otros significados adheridos. Los ingleses estaban rendidos a los pies de los argentinos. Un resabio colonial en el "fin del mundo" se liberaba [...] Los diez minutos que estuvieron los ingleses tirados en el piso de Malvinas se congelaron para la historia (Gamarnik, 2012, pp. 19-20).

A nivel internacional, la humillación y el maltrato de los soldados ingleses maniatados en el suelo por parte de los militares argentinos produjo también una asociación inmediata con el tema de las violaciones a los derechos humanos y la impunidad prevaleciente hasta esos momentos por parte de la dictadura. En los siguientes años, la tragedia de los conscriptos argentinos obligados a pelear en Malvinas y el registro documentado en la opinión pública de sus sufrimientos y vejaciones por parte de una cúpula militar que los arrancó de sus casas y los trasladó a territorios inhóspitos en los que a muchos sólo los esperaba la muerte representó otra vuelta de tuerca en la enorme densidad que adquirió el episodio de las Malvinas y su vinculación con el tema no resuelto de los desaparecidos en la memoria de la historia reciente argentina.

\section{CONSIDERACIONES FINALES. UN CICLO: DOS IMÁGENES}

Se puede ser de Boca, de River, de Estudiantes y hasta de Gimnasia y estar conmovido, emocionado por la recuperación de la identidad del nieto de Estela de Carlotto [...] Uno puede leer Página 12 o La Nación o Tiempo Argentino

\section{()(1) $(9$}


o Clarín, mirar TN o la Televisión Pública, despreciar o admirar a Mario Vargas Llosa, tener una foto de Néstor Kirchner en la billetera o detestar al presidente y al mismo tiempo coincidir en que la restitución de niños desaparecidos es un hecho maravilloso y ejemplar para el mundo [...] Podrá haber miles de discusiones entre nosotros. Pero hay algo que, al parecer, quedó claro. Hay un punto donde la grieta no llega. Podemos odiarnos por todo lo demás. O no. Pero aun odiándonos, la mayoría de nosotros se alegró cuando la vimos a Estela de Carlotto anunciar esa noticia tan feliz, tan justa, tan trascendente. Ahora, volvamos a putearnos, que vida hay una sola y está para disfrutarla.

Ernesto Tenembaum, Revista Veintitres, 2014.

Un momento simbólico del inicio de una nueva etapa en la construcción de una memoria en torno a los derechos humanos en Argentina, que lo mismo ha ampliado el ejercicio de la memoria que ha favorecido su institucionalización, está representado por una foto icónica que ha dado lugar a todo tipo de debates y discusiones en los últimos años en Argentina. Se trata de la famosa imagen del presidente Kirchner dando la orden al general Bendini de descolgar el retrato del dictador Videla en el Colegio Militar, el 24 de marzo de 2004.

En la versión del fotógrafo Víctor Bugge, en un encuadre horizontal, la cámara está situada atrás y a la derecha del presidente, en un primer plano, justo a su lado y a la altura de su mirada, lo que transmite una sensación de cercanía del lector, que le permite acercarse a la intimidad de este momento y recrear desde dentro uno de los episodios públicos más significativos de la historia argentina reciente.

En un ángulo de una contrapicada moderada, que resalta los cuadros de los retratos de los militares colgados en la pared, el centro de la imagen está ocupado por el cuadro del general Galtieri, pero el foco de la atención de la mirada de Kirchner y la de todos los lectores de esta imagen esta puesta en el cuadro de Videla, que ha roto con la simetría y ha perdido el horizonte visual en línea recta que compartía con los otros dos retratos para comenzar su descenso de las manos del primer ministro de las fuerzas armadas de un gobierno democrático.

\section{()(1) $(2$}


Vale la pena incluir el testimonio del propio fotógrafo, que aporta el contexto inmediato que permeaba todo el acontecimiento:

El ambiente no estaba bien entre los militares. Yo había escuchado los rumores de que el generalato se negaba a recibir a Kirchner: había negociaciones entre ellos, idas y vueltas, y hasta se decía que podía haber un escándalo. Al final lo recibieron todos formados en el hall del Colegio Militar. Néstor ingresa a un salón a la espera de que se acomoden las autoridades, y cuando Ceremonial le avisa que está todo listo, él dice: "Vamos". Entonces Bendini le pregunta: “Presidente, quién descuelga el cuadro?”. "Usted”, le responde Kirchner. Caminamos unos 200 metros, subimos al primer piso y frente a los distintos cuadros, Kirchner le dice a Bendini: "Proceda". Y Bendini procedió (Memoria en movimiento, 2012, p. 59).

Esta imagen se complementa con otra fotografía de María Eugenia Cerutti, quien captó el mismo instante, pero en otro ángulo, desde el costado izquierdo del presidente Kirchner (fotografía 12). Debido a ello, toma el perfil del mandatario en un primer plano, con su puño cerrado y apretado por la tensión del momento, y al fondo puede verse la reacción de algunos oficiales y soldados del ejército, que no despegan la mirada del cuadro de Videla.

La jerarquía icónica de esta imagen quedó confirmada en la exposición ya mencionada de los 30 años de fotoperiodismo en democracia, organizada por la asociación de Reporteros Gráficos y exhibida del 17 de julio al 18 de agosto de 2014 en el Palacio Nacional de las Artes de la ciudad de Buenos Aires. La foto en cuestión fue amplificada en dimensiones más grandes a la del resto de las fotos de la expo y fue expuesta junto con otras cuatro imágenes en el centro mismo del lugar, lo que da una idea de la jerarquía atribuida a este trabajo en relación con el tema central de la curaduría museográfica, esto es, la construcción de la democracia en Argentina.

Para algunos actores sociales, este carácter mítico tiene un ángulo negativo y demagógico, que sólo ha tergiversado la realidad, en la medida en que no resulta válido pretender eliminar a ningún personaje de la historia, lo cual incluye por supuesto a los dictadores, por más cruentos y fatídicos que hayan resultado sus gobiernos. El ejemplo al que se alude es el que se refiere a Stalin y la desaparición de Trotsky, no sólo a través de su asesinato el 21 de agosto de 1940 en el barrio de Coyoacán, al sur de la ciudad de México, sino por medio de la eliminación de toda referencia posterior a su figura como

\section{()(1) $(3$}




\section{SECUENCIA}

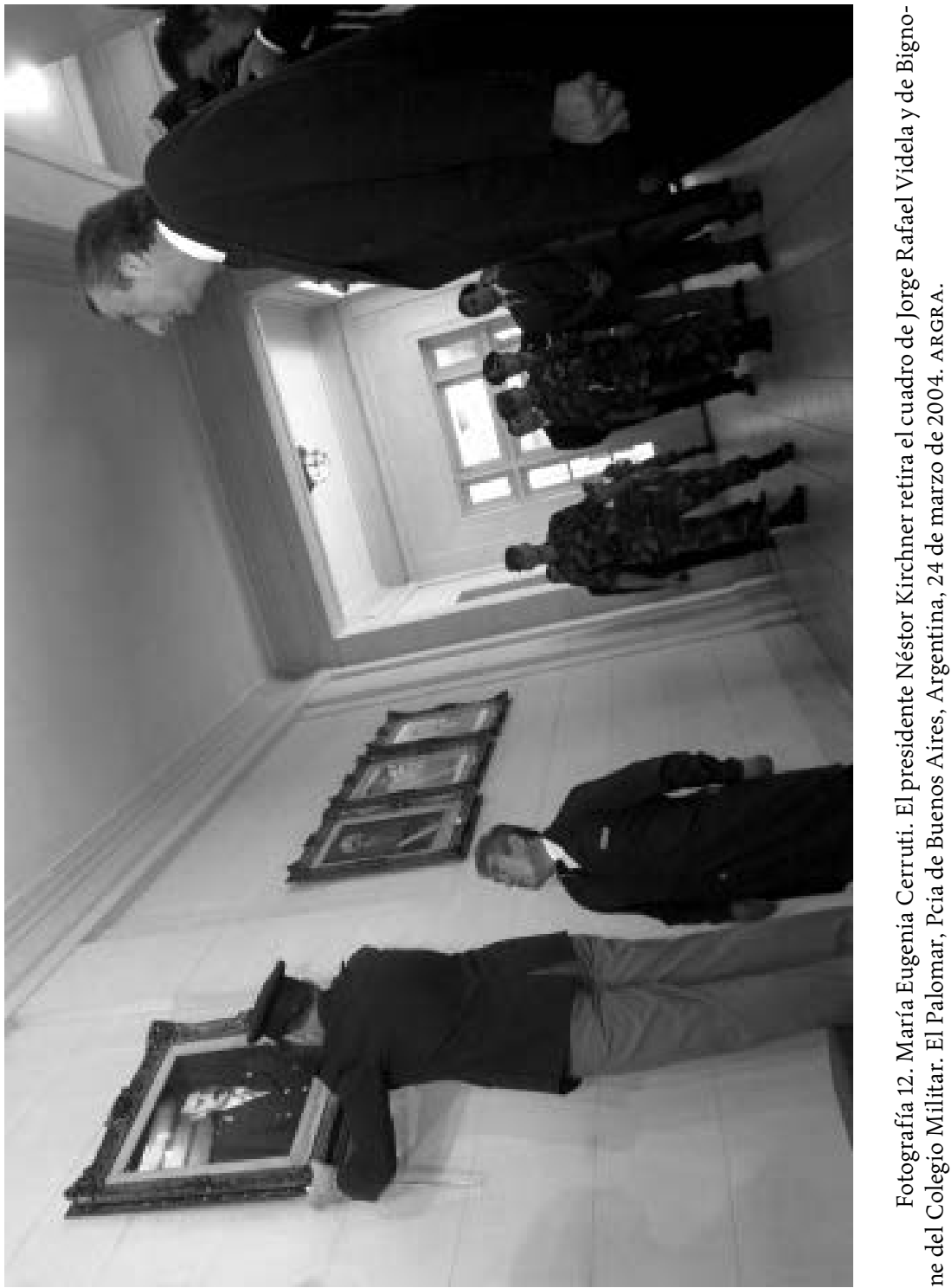

\section{(ㄷ)(1) $(8)$}


personaje histórico en la documentación fotográfica de algunos acervos y publicaciones de la Unión Soviética y sus aliados. ${ }^{20}$

En lo personal, discrepo de esta opinión, y considero que la fotografía en cuestión representa un símbolo icónico muy importante, el cual condensa una voluntad política por parte del Estado argentino en aquella coyuntura -en pleno aniversario del golpe militar- que marcaba así una diferencia con los gobiernos de la década anterior - que habían llegado a indultar a los militares- y transmite un mensaje político dirigido a todos los sectores, señalando el inicio de una nueva etapa de superación de la impunidad en el tema de los derechos humanos. Podemos considerar como icono a la imagen, en este caso fotográfica, que trasciende el espacio en el que fue dada a conocer de manera inicial y se convierte en una referencia visual para toda una generación a través de una divulgación más amplia. En lo personal, pude constatar la circulación y puesta en escena en distintos espacios urbanos de esta imagen en mantas, carteles, pintas, esténciles, graffitis y hasta playeras y camisetas, portadas por jóvenes y adultos durante la marcha del 30 aniversario del golpe militar, el 24 de marzo de 2014 en la ciudad de Buenos Aires, rebautizado hace un par de años por el Estado argentino en esta disputa por los símbolos como "Día de la memoria".

Cualquiera que sea la conclusión final respecto de los alcances del gobierno de Kirchner en esta materia -problemática que trasciende los límites de este trabajo-, lo que sí resulta importante subrayar en este artículo es el enorme peso simbólico de esta imagen, constructora de un sentido y un significado histórico muy precisos y uno de los iconos y referentes visuales más relevantes de una generación. En este sentido, se trata de un referente muy importante, que condensa un episodio y una coyuntura histórica determinada y que funciona como punto de partida y como interlocutor obligado, tanto para los sectores que están de acuerdo con el sentido de la imagen como -sobre todo- para los que no lo están.

La otra imagen icónica que cierra este círculo es la que se refiere a la fotografía de la presidenta de Abuelas de Plaza de Mayo, Estela de Carlotto, en la sede de dicha asociación, en la conferencia de prensa en la que anunció la recuperación de su nieto "Guido" (Ignacio Hurban), el número 114 de la

20 Tal es la opinión expresada por Héctor Leis, un militante del grupo de Montoneros hasta 1976, exiliado en Brasil al año siguiente y profesor en la Universidad Federal de Santa Catarina, en su diálogo con Graciela Fernández Meijde (Avelluto, Azzi y Racioppi, 2013).

\section{()(1) $\$$}


organización..$^{21}$ La noticia fue transmitida en la mayoría de los canales de televisión y estaciones de radio la noche del 5 de agosto de 2014, ocupó la primera plana de todos los periódicos y revistas al día siguiente, dio lugar a comentarios positivos de toda la clase política e incluso una carta personal del papa Francisco y una felicitación del Alto Comisionado de la onu y fue el principal tema de conversación en las redes sociales durante varios días, superando a cualquier otro episodio o acontecimiento local o internacional (fotografía 13).

El tema es muy significativo y tiene muchas aristas. Para los efectos de este artículo sólo quiero subrayar que el episodio es un indicador del nivel de legitimidad que ha alcanzado el tema de la recuperación de los nietos apropiados por los militares en la actual sociedad argentina, un asunto estrechamente vinculado con la problemática de los desaparecidos. El debate sobre este mismo punto era marginal a principios de los ochenta y estaba teñido por la sospecha y la incredulidad de amplios sectores permeados por el discurso oficial. Sin embargo, treinta años después representa una referencia de orgullo y pertenencia y es leída en general como la apertura de un escalón más en la construcción de la democracia por la mayor parte de la población. De esta manera, se ha transitado en tres décadas de la existencia de una memoria independiente o marginal a otra de carácter dominante, con todas las implicaciones que esto conlleva y cuyo análisis rebasa los límites de este artículo.

La evolución del fotoperiodismo representa uno de los hilos conductores centrales para revisar este proceso. La reflexión de autoras como la investigadora Cora Gamarnik nos ha servido para desentrañar desde qué lugares y a partir de qué referencias conceptuales se está leyendo este importante proceso en la historiografía argentina reciente. La crítica de fuentes documentales de esta autora es muy amplia y contempló la consulta de archivos fotográficos institucionales y de particulares, la revisión hemerográfica de distintos folletos, así como de las principales revistas y diarios de Chile, Argentina y Uruguay; la consulta de entrevistas y trabajos periodísticos publicados con distintos profesionales de la lente, la realización de entrevistas personales con algunos personajes como Nora Cortiñas, presidenta de Madres de Plaza de Mayo-Línea Fundadora y una diversidad de fotógrafos, entre los que cabe mencionar a César Cichero, Daniel García, Eduardo Longoni, Pablo Lasansky, Aldo Amura, Daniel Merle, Bécquer Casaballe, Marcelo Ranea y Carlos Pesce; el análisis de materiales de propaganda de las tres dictaduras conosureñas mencionadas,

21 "Guido" es el nombre que le dio Laura Carlotto a su bebé, el breve lapso que pudo tenerlo entre sus brazos, un par de semanas antes de ser asesinada por los militares (Ludueña, 2013).

\section{(이요}




\section{SECUENCIA}

Secuencia, ISSN 0186-0348, núm. 96, septiembre-diciembre de 2016, pp. 226-277

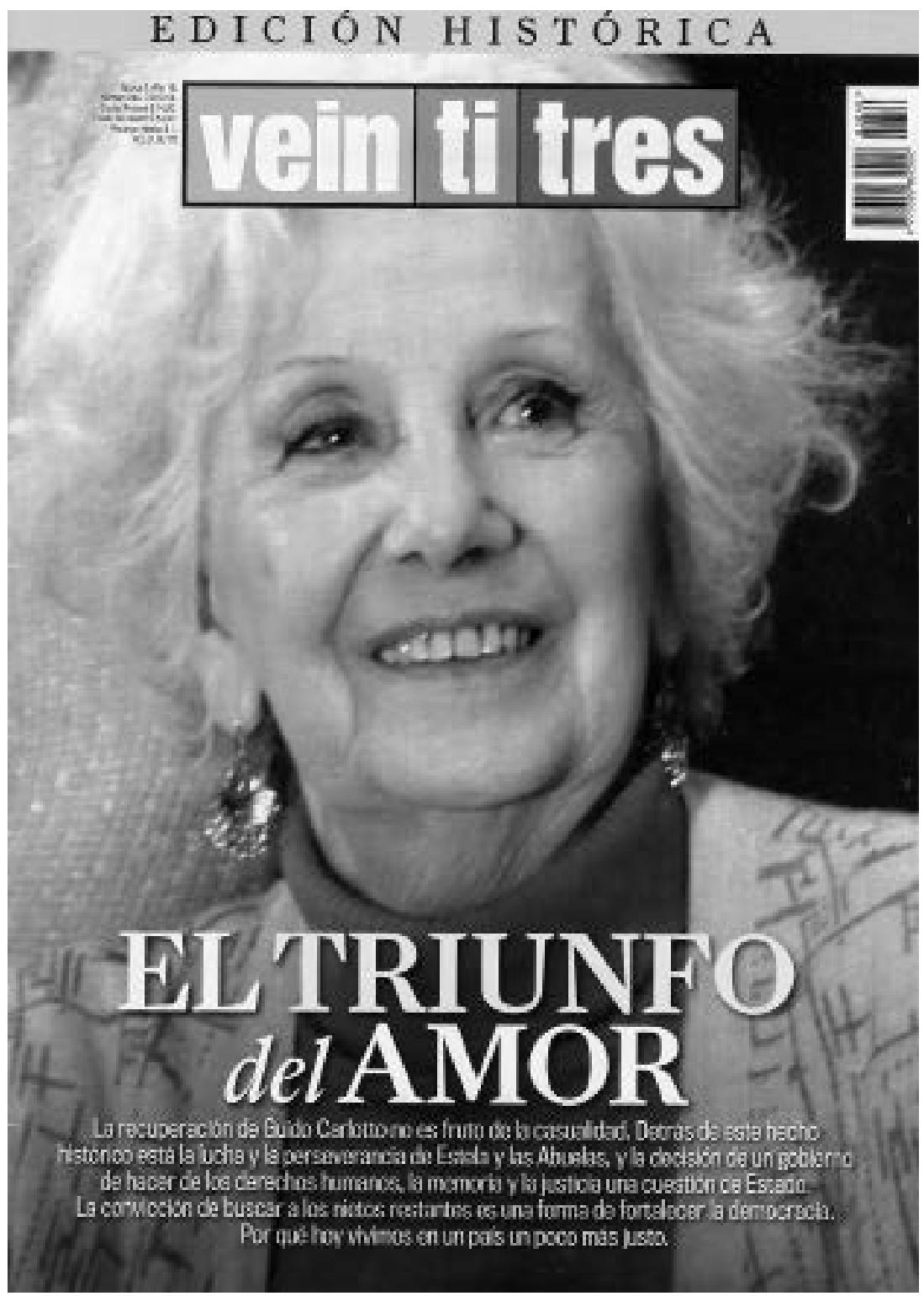

Fotografía 13. Estela de Carlotto. Portada de la revista Veintitrés, núm. 840, Buenos Aires, 7 de agosto de 2014. Colección particular.

\section{(ㅇ)(1) $(8$}


así como algunos documentales y sitios web y un diálogo con algunos de los trabajos de investigación histórica más importantes de aquellos años.

A través de estas páginas hemos mostrado algunas de las facetas del trabajo de investigación de Gamarnik, que representa una referencia clave para comprender los matices y las peculiaridades del fotoperiodismo en Argentina durante la dictadura.

Este artículo recupera una perspectiva general para atender un trabajo como el de Gamarnik, fragmentado y disperso en distintos artículos publicados en revistas académicas en los últimos quince años, que proporciona algunas de las claves analíticas más pertinentes para reflexionar sobre este tipo de procesos.

Como ha quedado documentado en este artículo, la mirada de la autora permite reconstruir las coordenadas del régimen de visibilidad del régimen militar, pero también atiende a los distintos procesos de resistencia encabezados por distintos sectores entre los que predominan las Madres de Plaza de Mayo y subraya la importancia de la construcción mediática que las posiciona en los espacios públicos, al tiempo que interroga la visión del mundo de los propios fotógrafos como creadores de imágenes.

Cabe concluir pues que estos son sólo algunos de los hitos referenciales de un proceso mucho más complejo, en el que intervienen otros investigadores y del cual hemos señalado aquí algunos puntos de partida que han servido para contextualizar este importante relato visual. Este tipo de lectura permite apuntar algunas pistas para una historia de la fotografía en América Latina en los años recientes. Como ha quedado documentado en este artículo, el trabajo de investigación de Cora Gamarnik representa un eslabón importante en la construcción de este proceso.

\section{LISTA DE REFERENCIAS}

Arendt, H. (2003). Eichmann en Jerusalen. Un estudio sobre la banalidad del mal. Barcelona: Lumen.

Avelluto, P., Azzi, C. y Racioppi, P. (dirs.) (2013). El diálogo. Documental. Buenos Aires.

Blejmar, J., Fortuny, N. y García, L. I. (2013). Instantáneas de la memoria. Fotografía y dictadura en Argentina y América Latina. Buenos Aires: Libraria Ediciones.

Castillo, A. del (2012). Rodrigo Moya. Una mirada documental. México: Instituto de Investigaciones Estéticas-UNAM/Ediciones El Milagro.

\section{(ㅇ)(1) $\$$}


Castillo, A. del (2013). Las mujeres de X’oyep. La historia detrás de la fotografía. México: Conaculta.

Castillo, A. del (2015). Entre el abrazo y el enfrentamiento. Un diálogo entre dos imágenes icónicas de fin de siglo en América Latina. En J. Mraz y A. M. Mauad (eds.), Fotografía e historia en América Latina (pp. 199-224). Montevideo: CDF ediciones.

Castillo, A. del (mayo-agosto, 2016). Fotografía y memoria en la dictadura argentina (1976-1983). Entrevista con Eduardo Longoni. Secuencia. Revista de Historia y Ciencias Sociales, 95, 215-258. DoI: http://dx.doi.org/10.18234/secuencia.v0i95.1383

Cerolini, P. (2006). En negro y blanco. Fotografías del Cordobazo al Juicio a las Juntas. Buenos Aires: ARgRA.

Feld, C. y Stites, J. (2009). El pasado que miramos. Memoria e imagen ante la historia reciente. Buenos Aires: Paidós.

Feld, C. (2012). Fotografía y desaparición en Argentina. Consideraciones sobre la foto de Alice Domon y Léonie Duquet tomada en el sótano de la ESMA. En A. Triquell y C. Feld, Artículos de investigación sobre fotografía (pp. 37-82). Montevideo: CDF ediciones.

Frizot, M. (1998). A new history of photography. New York: Ullman.

Gamarnik, C. (2010). La construcción de la imagen de las Madres de Plaza de Mayo a través de la fotografía de prensa. Afuera. Estudios de Crítica Cultural y Artes Visuales, año $V(9), 1-17$. Recuperado de www.revistaafuera.com

Gamarnik, C. (2011a). Imágenes de la dictadura militar. La fotografía de prensa antes, durante y después del golpe de Estado de 1976 en Argentina. En S. Pérez y C. Gamarnik, Artículos de investigación sobre fotografía (pp. 47-94). Montevideo: CDF ediciones.

Gamarnik, C. (2011b). El fotoperiodismo y la guerra de Malvinas: una batalla simbólica. En J. Mraz y A. M. Mauad, Fotografía e historia en América Latina (pp. 225256). Montevideo: CDF ediciones.

Gamarnik, C. (2011c). El nacimiento de un nuevo fotoperiodismo. Boca de sapo. Revista de Arte, Literatura y Pensamiento, 11, 20-29. Buenos Aires. Recuperado de: http:// www.bocadesapo.com.ar/biblioteca/bds/BdS11.pdf

Gamarnik, C. (2012). Fotografía y dictaduras: estrategias comparadas entre Chile, Uruguay y Argentina. Nuevo Mundo. Mundos Nuevos. DoI:10.4000/nuevomundo.63127.

Gamarnik, C. (2013). La fotografía irónica durante la dictadura militar argentina: un arma contra el poder. Discursos fotográficos, 9(14), 176-196. DoI: 10.5433/1984-7939.2013v9n14p173.

Gorini, U. (2006). La rebelión de las madres. Historia de las Madres de Plaza de Mayo. Buenos Aires: Norma.

\section{(ㄷ)(1) $(3$}


Jelin, E. y Longoni, A. (2005). Escrituras, imágenes y escenarios ante la represión. Barcelona: Siglo XXI.

Larraquy, M. (2013). Los 70. Una historia violenta. Marcados a fuego III (1973-1983). Buenos Aires: Aguilar.

Longoni, A. (2010). Fotos y siluetas: dos estrategias contrastantes en la representación de los desaparecidos. En E. Crenzel, Los desaparecidos en Argentina. Memorias, representaciones e ideas (1983-2008). Buenos Aires: Editorial Biblos.

Ludueña, M. E. (2013). Laura. Vida y militancia de Laura Carlotto. Buenos Aires: Planeta.

Lvovich, D. y Bisquert, J. (2008). La cambiante memoria de la dictadura. Discursos públicos, movimientos sociales y legitimidad democrática. Buenos Aires: Universidad Nacional de General Sarmiento.

Mauad, A. M. (2011). Poses y flagrancias. Brasil: Universidad de Río de Janeiro.

Memoria en movimiento (2012). 76.11 fotos. El otro lado de la cámara. Buenos Aires: Presidencia de la Nación/Universidad Nacional de San Martín.

Monroy, R. (2008). Ética de la visión: entre lo veraz y lo verosímil en la fotografía documental. En I. de la Peña (coord.), Ensayos sobre fotografía documental. México: Siglo XXI.

Moreno, L. (2014). Cuando el poder perdió el juicio. Buenos Aires: Capital Intelectual.

Mraz, J. (2008). El aura de la veracidad ética y metafísica en el fotoperiodismo. En I. de la Peña (coord.), Ensayos sobre fotografía documental. México: Siglo XXI.

Mraz, J. y Arnal, A. (1996). La mirada inquieta. México: Centro de la Imagen.

Nilson, C. (1988). Operativo Cóndor. Terrorismo de Estado en el Cono Sur. Buenos Aires: Lumen.

Novaro, M. (2010). Historia de la Argentina 1955-2010. Buenos Aires: Siglo XXI.

Pérez, S. y Gamarnik, C. (2011). Artículos de investigación sobre fotografía. Montevideo: CDF ediciones.

Renán, S. (dir.) (1979). La fiesta de todos. Documental. 110 min. Color. Argentina.

Rorty, R. (1966). Contingencia, ironía y solidaridad. Barcelona: Paidós.

Vezzetti, H. (2001). Conflictos de la memoria en Argentina. Lucha armada en la Argentina, 2, p. 46.

\section{OTRAS FUENTES}

Archivo Memoria Abierta. Ciudad de Buenos Aires, Argentina.

Museo de la Memoria de Rosario, Argentina.

\section{(ㅇ)(1) $(3$}




\section{Bibliografía}

Almeida, M. (2003). Temas pendientes: la izquierda francesa y alemana frente al campeonato mundial de futbol Argentina 1978. Anales del IAA, 43 (1), 21-36. Recuperado de: http://www.iaa.fadu.uba.ar/ojs/index.php/anales/article/viewFile/100/88

Gamarnik, C. (2009). Reconstrucción de la primera muestra de periodismo gráfico argentino durante la dictadura. Ponencia presentada en las V Jornadas de Jóvenes Investigadores. Instituto Gino Germani, Buenos Aires.

Tornay, L. (2012). Imágenes del terrorismo de Estado en Argentina. Temporalidades de las narrativas. Ponencia presentada en el Congreso Internacional Ciencias, tecnologías y culturas. Diálogo entre las disciplinas del conocimiento. Mirando al futuro de América Latina y el Caribe, Santiago de Chile. 